Research Report No. 18/2010

\title{
Digital Locks and the Fate of Fair Dealing in Canada: In Pursuit of 'Prescriptive Parallelism'
}

Carys J. Craig

Osgoode Hall Law School of York University, ccraig@osgoode.yorku.ca

Follow this and additional works at: http:// digitalcommons.osgoode.yorku.ca/clpe

\section{Recommended Citation}

Craig, Carys J., "Digital Locks and the Fate of Fair Dealing in Canada: In Pursuit of 'Prescriptive Parallelism'" (2010). Comparative Research in Law \& Political Economy. Research Paper No. 18/2010.

http://digitalcommons.osgoode.yorku.ca/clpe/85 


\title{
OSGOODE HALL LAW SCHOOL
}

Comparative Research in Law \& Political Economy

\author{
RESEARCH PAPER SERIES
}

Research Paper No. 18/2010

\section{Digital Locks AND the Fate of FaIR DeALING IN CANADA: IN PURSUIT OF "Prescriptive Parallelism"}

Carys J. Craig

Editors:

Peer Zumbansen (Osgoode Hall Law School, Toronto, Director, Comparative Research in Law and Political Economy) John W. Cioffi (University of California at Riverside) Lisa Philipps (Osgoode Hall Law School, Associate Dean Research)

Nassim Nasser (Osgoode Hall Law School, Toronto, Production Editors) 
CLPE Research Paper 18/2010

Vol. 06 No. 5 (2010)

\title{
Carys J. Craig
}

\section{Digital Locks and the Fate of Fair Dealing in Canada: In Pursuit of "Prescriptive Parallelism"}

\begin{abstract}
The enactment of anti-circumvention laws in Canada appears imminent and all but inevitable. This article considers the threats posed by technical protection measures and anticircumvention laws to fair dealing and other lawful uses of protected works, and so to the copyright system more generally. The argument adopts, as its normative starting point, the principle of "prescriptive parallelism" according to which the traditional copyright balance of rights and exceptions should be preserved in the digital environment. Looking to the experiences of other nations, the article explores potential routes towards reconciling technical protection measures with copyright limits, and maintaining a substantive continuity in Canada's copyright balance. It offers some proposals for digital copyright reform that could meet the principled demands of prescriptive parallelism, limit the impact of digital locks on the cultural landscape, and save fair dealing from its impending fate.
\end{abstract}

Keywords: Copyright, Canada, Anti-Circumvention, Fair Dealing, Public Domain

JEL Classification: K39, O33, O34, 038

\author{
Carys J. Craig \\ Associate Professor, \\ Osgoode Hall Law School
}




\title{
Digital Locks and the Fate of Fair Dealing in Canada: In Pursuit of "Prescriptive Parallelism"
}

\author{
Carys J. Craig*
}

\section{INTRODUCTION}

Digital technologies have dramatically changed the dynamics of cultural exchange in Canada. Content and information resources can be accessed, shared, reproduced, and re-used with more ease and efficiency than ever before. Consumption and creation intertwine and merge in the cultural space that the Internet offers up. At the same time, content providers faced with the new realities of networked society have an unprecedented capacity to control the access to and use of cultural materials beyond the moment of their distribution, by employing technical protection measures [TPMs] or so-called "digital locks." Within this new cultural space, efforts to retain control over the products of creative expression have taken on a renewed urgency for owners and a heightened practical significance for the general public.

A TPM is "a technological method intended to promote the authorized use of digital works" (Kerr et al., 2002-2003, p. 13). As Kerr, Maurushat and Tacit explain in their excellent report on TPM protection:

This is accomplished by controlling access to such works or various uses of such works, including copying, distribution, performance and display. TPMs can operate as safeguard or 'virtual fences' around digitized content, whether or not the content enjoys copyright protection. Two common examples of TPMs are passwords and cryptography (Kerr et al., 2002-2003, p. 13).

As this description suggests, TPMs can be classified by their function, which may be to control access or to control use. ${ }^{1}$ In the former case, a TPM operates as a "virtual lock" that excludes outsiders from the digital content; in the latter case, the TPM controls uses that can be made of that content even once accessed-most commonly, although not necessarily, preventing the making of copies (Kerr et al., 2002-2003, pp. 19-20).

The use and legal protection of TPMs may appear at first glance to be a peripheral issue at the margins of copyright policy, of interest to a limited number of technophiles-or indeed hackers - with a working knowledge of circumvention technologies, and a few intellectual property lawyers and academics. The issue, however, is far more sweeping. In our networked

\footnotetext{
* Carys J. Craig (LL.B.(Hons), LL.M., S.J.D.) is an Associate Professor of law at Osgoode Hall Law School, York University, in Toronto, Canada, where she teaches in the field of intellectual property.
} 
society, our culture is digitized; our information, news, research and educational resources and entertainment all come to us in digital packets. Increasingly, the way in which consumers access, use and consume digital content is the way in which we, as citizens, explore, experience and engage with our cultural environment. When it comes to technical and legal controls over intellectual works, the ability of the public to actively and meaningfully participate in our culture is at stake.

This article considers the impact of TPMs on content users and the wider public interest. In particular, it is concerned with the tension between the impending legal protection of TPMs and the user rights that are part of Canada's copyright system. TPMs, and the laws that prevent their circumvention, have the capacity to undermine the exceptions and limitations found in traditional copyright law, and thereby disrupt the "copyright balance" that the law is expected to strike. As a signatory to the World Intellectual Property Organization (WIPO) Internet Treaties, it seems all but inevitable that Canada will enact anti-circumvention provisions in the near future. Canadians have already seen two failed efforts in this regard, in the course of an ongoing and increasingly hard fought digital copyright reform process. While we anticipate the next iteration of an amendment to the Copyright Act intended to "respond to the challenges and opportunities of the digital age" (Government of Canada, 2008b), we have a fleeting opportunity to critically assess the values and vulnerabilities at play in the legal protection of TPMs.

My argument adopts, as its normative starting point, the principle of "prescriptive parallelism" according to which "the traditional copyright balance of rights and exceptions should be preserved in the digital environment" (Reichman et al., 2007, p. 1042). I suggest that the anticircumvention provisions of the earlier reform bills did not meet the demands of prescriptive parallelism because they failed to protect the role of fair dealing and copyright exceptions that the Supreme Court of Canada has recognized as integral to the copyright system. Accepting (albeit reluctantly) the likelihood of new protections for digital locks in Canada's revised Copyright Act, this article considers whether and how a substantive continuity in the existing "copyright balance" could be achieved. It may still be possible to construct this new layer of legal protection around the existing corner-stones of copyright policy, limiting the impact of digital locks on our cultural environment, and saving fair dealing from its impending fate-but Canada risks passing up the opportunity.

The article begins by providing some brief background on the role of TPMs in the distribution of digital content, and how they came to be entwined with copyright policy. It goes on to describe the ways in which TPMs and anti-circumvention laws threaten to upset the copyright balance by supplanting the traditional boundaries of the copyright interest and undermining the central role of fair dealing and the public domain within the Canadian copyright system. It then explores the interaction of anti-circumvention laws and copyright limitations in various international and foreign domestic laws, as well as specific measures that have been taken in other jurisdictions in the attempt to vindicate user rights and preserve the traditional balance of interests. The discussion then turns to the Canadian context, assessing Canada's two "false starts" in the race to implement anti-circumvention laws, identifying best practices and 
proposing some preferred solutions for Canada. The article concludes with a larger cautionary note about the potential impact of TPMs and their protection on the Canadian cultural landscape.

\section{THE BACKGROUND: TPMS AND COPYRIGHT LAW}

\section{A. The Promise and Threat of Digital Technologies}

If it is generally agreed that the copyright system is aimed (at least in part ${ }^{2}$ ) at maximizing creative opportunities, furthering the exchange of knowledge and preserving a vibrant public domain, then the potential of networked technologies to further the objectives of copyright is undeniable. These technologies have created previously unimagined opportunities for easy and affordable creative play, the potential for virtually unlimited and instantaneous communication across cultural and geographic boundaries, and an unparalleled space for discursive engagement. Viewed in this light, it seems almost surprising, and certainly disappointing, that the recent focus of IP policy-makers has been predominantly on the threats rather than the promises of digital technology. This focus is indicative of fear. The emergence of the digital world has rapidly generated a new public idea of discourse, participation, and production-one that values networking over singularity, and relationships over individuation. Most importantly, however, this new public idea favours a collaborative model of shared and cumulative cultural dialogue over a proprietary model of cultural production. In the very same way, and for the very same reasons, that digital technologies promise to advance the overarching aims of copyright policy, they threaten to undermine or unseat the underlying methods and mechanisms of the copyright system.

At a more practical level, this paradox translates into a digital dilemma for IP owners and traditional content providers, which is manifested in their frequently reluctant or ambivalent foray into the online environment. While they may indeed stand to benefit from more efficient production and distribution of information products, rightholders and industry actors are often more concerned that any such benefits will be undercut by the increased threat of reproduction and unauthorized dissemination that new technologies entail. Of course, much has been made of the threat posed by the Internet to traditional content industries and their intellectual properties. As individual consumers acquire the ability to circulate perfect, costless copies, the anxiety is well-founded: conventional business models are jeopardized, existing markets evaporate and long-time industry actors are effectively supplanted. Loss of control over distribution can translate into lost sales, and potentially the loss of a viable market for digital content.

In the face of this threat, many rightholders opt to resist the full implications of the digital shift, strongly asserting their proprietary interests and employing TPMs to control the digital distribution and use of content. By providing a practical means to ensure excludability and control, TPMs are viewed by many as the key to ensuring a viable market for digital products and services in the online environment. Just as the promises of digital technologies for 
rightholders are tempered by the threat of uncontrolled reproduction, the promises of digital technologies for content users are thus tempered by the threat of increased control made possible by TPMs.

While owners develop and employ TPMs to protect content, however, users develop new technologies to circumvent them, resulting in what has been described as a technical "arms race" that is destined never to be won. Turning to the law, demands are made for more regulation to support owners' efforts to maintain control in the face of the "Internet Threat." The assumption is that the moving target of perfect control can be struck only through the perfect interplay of technical architecture and legal force. ${ }^{3}$

It is understandable that certain copyright owners welcome TPMs to assist them in the profitable distribution of digital content-but it is less clear what TPMs have to do with the law of copyright as such. Of course, TPMs can be added to the copyright owner's arsenal against unauthorized users, complementing the rights granted by law. But arguably, technology and intellectual property are best viewed as separate and distinct sources of empowerment, just as traditional property and intellectual property law have always been. The scarcity of the physical embodiment of a work (a painting, say) may contribute to a rightholder's capacity to control the work's distribution, but copyright is not concerned with the ownership of the physical thing; if that painting is stolen, for example, copyright law is simply not implicated. Similarly, the application of TPMs to a digital embodiment of a work may practically aid in limiting distribution of that work-but traditional copyright law has no necessary stake in whether or how that TPM is applied or respected. Technical controls enable owners to side-step some of the costs and practicalities associated with the assertion of legal rights (providing an effective second layer of protection), but it does not naturally follow that legal rights should be expanded to protect the application of TPMs (thereby effectively establishing a third layer of protection).

\section{B. The EMergenCe of Anti-CIRCUMVEntion LaWs}

While it requires a logical leap to assume TPMs within the copyright system, it is a leap that has been taken at the international level, and consequently, by domestic legislatures around the world. This development traces back to a 1995 US government White Paper (1995), which recommended outlawing technologies whose primary purpose or effect is to bypass TPMs. The White Paper explained that, in the digital environment, copyright owners would increasingly turn to technology to protect their rights, but that technology would be found wanting in the absence of new laws to protect it. ${ }^{4}$ The suggested prohibition on TPM-circumventing devices was thus "intended to assist copyright owners in the protection of their works" (White Paper, p. 231) and, rationalized in these terms, it was proposed as an amendment to the U.S. Copyright Act. While the White Paper recommendations stalled in the face of domestic opposition (see Litman, 2001, pp. 122-9), a draft treaty mirroring its proposals was distributed for consideration at the WIPO international diplomatic conference in Geneva in 1996. 
WIPO negotiations culminated in the WIPO Copyright Treaty (WCT) and the WIPO Performances and Phonograms Treaty (WPPT). ${ }^{5}$ The adopted treaty texts rejected or diluted some of the most highly protectionist provisions of the White Paper (Litman, 2001, pp. 129$30),{ }^{6}$ including the proposed prohibitions relating to circumvention devices or services. But key provisions introduced new protection for digital works in the form of legal protection against the circumvention of TPMs. ${ }^{7}$ However, the final text of the anti-circumvention provision in the WCT-which is paralleled in Article 18 of the WPPT ${ }^{8}$ - diverges significantly from the original US proposal and instead reflects an international compromise:

Contracting Parties shall provide adequate legal protection and effective legal remedies against the circumvention of effective technological measures that are used by authors in connection with the exercise of their rights under this Treaty or the Berne Convention and that restrict acts, in respect of their works, which are not authorized by the authors concerned or permitted by law (WCT, Article 11).

Article 11 of the WCT leaves member states with significant latitude when it comes to implementing the treaty obligation in domestic law. First, the Treaty requires only "adequate" legal protection and "effective" legal remedies, leaving room for domestic legislatures to determine what is required of their laws in order to meet this subjective standard. Indeed, the Treaty does not require anti-circumvention provisions to be included in copyright legislation at all; if "adequate" protection and remedies are available through other legal routes, then Article 11 will be satisfied (Samuelson, 1996). ${ }^{9}$ As Michael Geist explains, "any national legislation will be measured against an adequacy criterion such that the legal protections must provide some measure of protection that a reasonable person would perceive as evidencing effectiveness" (Geist, 2005, p. 223). In this way, the language of Article 11 reflects the ambivalence or uncertainty that surrounded the creation of legal protection for TPMs in the international arena, and evidences the level of generality that was necessary to garner sufficient support for its inclusion in the Internet Treaties.

Furthermore, as Kerr and his co-authors explain, pursuant to this section, "the only TPMs subject to legal protection against circumvention are those that: (a) are effective; (b) are used by authors to exercise copyrights; and (c) restrict acts not authorized by authors or permitted by law" (Kerr et al., 2002-2003, p. 34; citing Koelman and Helberger, 2000, p. 171). The meaning of "effective" in this context is unclear. It is widely understood to mean that ineffective TPMs (presumably those that can be easily and cheaply circumvented) may not demand the benefit of the legal protections guaranteed by the Treaty. What this means in practice is murkier still, as most if not all TPMs can be circumvented-indeed this is the assumption behind the creation of additional legal protection. The only clear conclusion is that "not every TPM is subject to legal protection" under the WCT (Kerr et al., 2002-2003, p. 35).

More important for our purposes, however, are restrictions (b) and (c), which, taken together, appear to mean that member states are obligated to provide protection only in respect of TPMs 
that are used by authors in connection with the exercise of their copyright-and only to the extent that a TPM is used to restrict unauthorized acts that the law does not permit in relation to their protected works. Simply put, the protection afforded to TPMs under the treaties appears to coincide with the scope of copyright proper (Koelman, 2000); the treaties are concerned specifically with circumvention activities that facilitate copyright infringements (Wiese, 2002, p. 150). If TPMs must restrict acts protected by copyright law in order to benefit from protection pursuant to Article 11, then it would seem to follow that there is no obligation, under the WCT, for a member state to prohibit circumvention activities that do not result in copyright infringement. According to this reading of Article 11, circumvention of TPMs for lawfully permitted purposes such a fair dealing are beyond the scope of the protection that the Treaty requires. ${ }^{10}$

With the WIPO Internet Treaties, TPM protection became part of an international strategy for tackling the challenges to copyright law presented by digital technologies. Consequently, anticircumvention legislation has emerged as a prominent component of the domestic copyright reform agenda. As a signatory to the WIPO Internet Treaties, Canada is now faced with the prospect of ratifying the treaties and bringing its laws into compliance with them. It is important to stress, however, that Canada has not yet assumed any international legal obligation by virtue of signing the treaties. As Howard Knopf has evocatively explained, signing a treaty is to ratification about the same as what dating is to marriage (Knopf, 2008). ${ }^{11}$ Whether or not Canada ought to ratify the treaties is primarily a political question, which puts into play a myriad of practical and pragmatic considerations that reach far beyond Canadian copyright policy. But it is clear enough at this time that all political indicators are pointing in the direction of ratification, with the government actively working towards amendments to the Copyright Act that "would implement the rights and protections found in the treaties."12

Before we consider preferred approaches to the legal protection of TPMs in Canada, the potential significance of anti-circumvention provisions should be situated against the backdrop of Canadian copyright policy in general, and our fair dealing defence in particular. The following section aims to articulate the problems posed by TPMs, and the potential of anti-circumvention laws to tip Canada's copyright balance in favour of owners at the expense of users and the public.

\section{The Problem With TPMS: TipPing the Copyright BalanCe}

\section{A. The Copyright Balance in Canada}

Copyright law is continuously challenged by its own "paradox": the interminable challenge is to construct a system that uses exclusivity to stimulate the creation and dissemination of works for the benefit of public without unduly harming the public interest by restricting the ability to access and use the works that are thus created. Fundamentally, the incentive-based approach 
to copyright policy assumes that the restriction of the public's use of works through the creation of private rights can further the public's interest in the widespread creation and distribution of works. The limits to these private rights, defined by fair dealing and other exceptions-and circumscribed by the boundaries of the public domain-are therefore essential to ensure that the copyright system does not inadvertently undermine its own ends.

In recent years, the Supreme Court of Canada has articulated the purposes of Canadian copyright law, and has acknowledged the inherent tensions that these purposes present, as well as the vital role that fair dealing and the public domain must play in alleviating them. In Théberge $v$ Galerie D'Art du Petit Champlain Inc. (Théberge), the Supreme Court identified copyright's purpose as "a balance between promoting the public interest in the encouragement and dissemination of works of the arts and intellect and obtaining a just reward for the creator." The Court went on to explain, "[t]he proper balance among these and other public policy objectives lies not only in recognizing the creator's rights but in giving due weight to their limited nature. In crassly economic terms it would be as inefficient to overcompensate artists and authors for the right of reproduction as it would be self-defeating to undercompensate them" (Théberge, per Justice Binnie, paragraphs 30-31).

As copyright law struggles to adjust to the proliferation of digital technologies, owners demand ever-increasing protection, and legislative reform looms large, these important pronouncements on the nature of the Canadian copyright system have come at a critical time. The Théberge decision represented a crucial moment in Canadian copyright policy, cementing a vision of copyright as a system intended not only to protect the rights of authors and their assignees, but also (and equally) to further the wider public interest. In describing how the metaphorical balance might be struck, it brought into the equation and attributed "due weight" to the limits of the rights that the system protects. Regarded in this way, the boundaries and limitations of the copyright interest are not external to copyright policy; they are a central part of how the system works.

With this in mind, the overarching problem associated with the widespread use of TPMs in the dissemination of digital content is simple enough to state: TPMs do not-and generally cannot-distinguish between lawful and unlawful uses and users. There is no necessary (and, typically, no practical) correlation between the limits imposed on would-be users by TPMs and the rights granted to copyright owners under the law; the scope of protection afforded by technology just does not map onto the protection afforded by law. While the law attempts to achieve balance between owners and users through careful circumscription of the copyright interest that it creates, technology effectively supplants the law's solution, usurping its power to effectuate this delicate balance. The mismatch between technical control and the boundaries of the copyright interest is easily discerned both with regard to the kinds of activities that owners can prevent or control, and the extent of the protected work that can be subject to such control.

\section{The Power to Control Access}


First, simply by blocking access to content, TPMs provide protection beyond that granted to copyright owners by law. Activities such as reading, listening, and viewing have always been perfectly lawful-and of course desirable from a cultural policy perspective-in the analogue world. Nothing in the law of copyright would prohibit someone from flipping through a magazine in the doctor's office, borrowing a novel from a friend, listening to a roommate's music collection, or watching a movie on a home video machine. With the application of TPMs to the digital embodiments of such works, however, the ability to read, listen to or view them can be made subject to the possession of a "digital key."

In the Théberge decision, the Supreme Court stated that "once an authorized copy of a work is sold to a member of the public, it is generally for the purchaser, not the author, to determine what happens to it" (paragraph 31). TPMs thoroughly disrupt this premise (deBeer and Geist, 2008, p. 173). In the analogue world, a person can re-read a favourite novel until it is in tatters, listen obsessively to a favourite record, devotedly watch and re-watch a favourite movie, and then sell or give away the novels, records and videos with which they finally grow bored. In the world of technical controls, reading, listening or viewing can be limited by the number of plays, the number (or even brand) of machines on which content can be played, the time during which the content is available and/or the identity of the would-be listener or viewer. This new reality, largely made possible by the operation of TPMs, has raised concerns about the social implications of eroding free use in the shift to a "pay-per-use" culture (see Secor, 1997). ${ }^{13}$

By affording owners the power to control pure access to works, TPMs go further than copyright protection ever has. And to the extent that access controls are themselves protected by anticircumvention laws, these laws effectively establish a legal right to control access (an "access right" if you will [see Ginsburg, 1999, pp. 140-3, 147-8; Koelman, 1999]) heretofore alien to copyright law. The implications of such control for copyright policy are incredibly significant. As Jane Ginsburg explains, "[e]very act of perception or of materialization of a digital copy requires a prior act of access. And if the copyright owner can control access, she can condition how a user apprehends the work...." (2001, p. 2).

Ginsburg has famously argued that, with the arrival of the digital age, the exploitation of works has shifted from possessing copies to "experiencing" a work's content-and this new end-user reality calls for a new balancing of rights in the digital era, which may entail an access-right for authors (1999, p. 5). ${ }^{14}$ Certainly, Ginsburg is right to remind us that the very metaphor of balance signifies the need for constant monitoring and adjustment to maintain normative consistency in changing circumstances. I would suggest, however, that the creation of a new "right against the gaining of unauthorized access" does not regain copyright's equilibrium, but tips the balance in favour of owners, to the detriment of users and the public, whose access to cultural resources and freedom to engage in basic consumptive activities may be radically restricted by such a right.

While TPMs create the power to control access, anti-circumvention laws establish a "new rights structure," restricting public uses that have long been viewed as acceptable and desirable (Heide, 2001, p. 14). As Thomas Heide warns, then, "we should recognize the very real 
possibility that access control mechanisms and not copyright will come to regulate the use of creative works" (2001, p. 18), thereby threatening the integrity of the copyright system.

\section{Power over the Public Domain}

The mismatch between copyright's boundaries and the constraints imposed by TPMs is further exemplified in the case of public domain materials kept behind digital locks. In addition to the legal, economic and transactional obstacles of traditional copyright law, the value of the public domain is now subject to the technological barriers that can prevent access to even IP-free information resources. An obvious concern here is the technical protection of works in which copyright protection has lapsed. While the copyright interest in a work exists for a limited (if long) period of time, TPMs can continue to erect a barrier around works after their legal entrance to the public domain, thereby undermining a crucial aspect of copyright policy: the limited duration of private rights has been a fundamental characteristic of copyright from its inception, and reflects the "deal" that copyright strikes between the public and the author. To grant legal protection over TPMs that protect public domain content is to supplant copyright's time-limited protection with a conceivably perpetual legal right to control access and restrict use of cultural resources.

One response, consistent with WIPO treaty obligations, ${ }^{15}$ may be to limit the protection of TPMs to those that control copyright-protected content, but this offers no solution where the content behind the digital lock includes both protected and public domain works. And while it may be argued that many or most public domain works will also be available from other TPMfree sources, to require members of the public to find and use unencrypted versions may deprive them of the benefits (including accessibility, quality and manipulability) of digitized or technologically superior versions. Not only does this argument accept an impoverished public domain, but it may also prove short-sighted as more and more of our culture is recorded, stored and archived in digital form.

The public domain objection to TPMs is even more significant when we recall that the divide in copyright law between public and private traverses the protected work; while copyright vests in the overall work, the ideas, information, systems, methods, mergers and unoriginal elements within it continue to reside in the public domain (Samuelson, 2003, p. 151). As explained by the Supreme Court of Canada, such limits on the author's right leave room for the production of "new works by building on the ideas and information contained in the works of others" (CCH Canadian Ltd. v Law Society of Upper Canada (CCH), paragraph 23), ${ }^{16}$ which in turn allows "the public domain to flourish" ( $\mathrm{CCH}$, paragraph 23). Or, as Jessica Litman famously described it: "The public domain should be understood not as the realm of materials that is undeserving of protection, but as a device that permits the rest of the system to work by leaving the raw material of authorship available for authors to use" (Litman, 1990, p. 967). The copyright balance thus demands that public domain elements of the protected work remain free for lawful and unauthorized public use. TPMs can make these public domain elements practically unavailable, while anti-circumvention laws can make access to and use of these public domain elements unlawful. We would do well to heed Justice Binnie's warning in this regard: "Excessive 
control by holders of copyrights and other forms of intellectual property may unduly limit the ability of the public domain to incorporate and embellish creative innovation in the long-term interests of society as a whole, or create practical obstacles to proper utilization" (Théberge , paragraph 32).

In order to occupy its central role in cultural practices, the public domain must be accessible to creative actors; but rather than protecting the rights of the public to access and use resources in the public domain, anti-circumvention laws protect the right to lock-up these resources. Technological protection erects a fence around the entirety of a work without discriminating between protectable and unprotectable elements; to electrify these fences with the force of the law is essentially to reinforce privately drawn boundaries around public resources.

\section{Displacing Fair Dealing}

Finally, the clash between copyright policy and TPMs reveals itself in the predicament of fair dealing and other copyright exceptions. ${ }^{17}$ The fair dealing defence permits fair dealings with copyright protected works for the purposes of research or private study, criticism or review, or news reporting (Copyright Act, sections 29-29.2) ${ }^{18}$ Acts undertaken for these purposes that would prima facie constitute infringement, are nonetheless lawful if found to be fair, and if-in the case of criticism, review or news reporting-there is sufficient acknowledgement of the source and author of the protected work. ${ }^{19}$ Further specific exceptions are found in the Act for e.g., educational institutions, libraries, archives and museums (sections 29.3-30.9).

In order to appreciate the significance of the clash between digital locks and fair dealing, it is important to understand the role that fair dealing and other exceptions play in the copyright system. In $\mathrm{CCH}$, the Supreme Court reaffirmed the concept of a copyright balance, ${ }^{20}$ and its significance in relation to copyright exceptions:

[T]he fair dealing exception, like other exceptions in the Copyright Act, is a user's right. In order to maintain the proper balance between the rights of a copyright owner and users' interests, it must not be interpreted restrictively. As Professor Vaver has explained, 'User rights are not just loopholes. Both owner rights and user rights should therefore be given the fair and balanced reading that befits remedial legislation' ( $\mathrm{CCH}$, paragraph 48$)$.

In the name of balance, the Court generously interpreted the fair dealing provisions in order "to ensure that users' rights are not unduly constrained" (CCH, paragraph 51). ${ }^{21}$ Against the backdrop of copyright's public purpose, fair dealing was recognized to be integral-not exceptional-to the system. Chief Justice McLachlin wrote: "the fair dealing exception is perhaps more properly understood as an integral part of the Copyright Act than simply a defence. Any act falling within the fair dealing exception will not be an infringement of copyright" ( $\mathrm{CCH}$, paragraph 48). Put otherwise, fair dealing does not merely excuse infringement, but rather defines it; the owner's rights end where the user's rights begin. Following the $\mathrm{CCH}$ decision, it should be clear that, rather than a marginal exception to the 
norms of Canadian copyright law, the fair dealing defence is an instantiation of the publicauthor balance; one that is necessary to support the normative claims so often made on behalf on the system. As Drassinower (2005) explains: "the defence of fair dealing... is to be understood and deployed not negatively, as a mere exception, but rather positively, as a user right integral to copyright law" (p. 467).

It is also important to underscore, at this juncture, the potential significance of the term "users' rights" employed by the Supreme Court. Much has been made of this terminology and the equality it brings to the balancing of authorial and public claims (see Craig, 2005, pp.454-5). For the purposes of my argument, however, its importance lies primarily in the positive nature of a "user right," in contrast to the negative nature of mere defences, justifications, exemptions or even privileges. A basic Hohfeldian analysis (Hohfeld, 1946) reveals that, when conceptualized as a privilege, fair dealing establishes only the liberty or freedom to act: the owner has no right to prevent the privileged activity, and the user owes no duty to refrain from the activity. But conceptualized as a right, fair dealing establishes a corresponding duty on behalf of the owner to honour the user's right: in this analysis, the user has a positive claim-right against the copyright owner to be permitted to deal fairly with the work. Where fair dealing is recognized as a "user right," it can be argued that copyright owners have a correlative obligation to permit users' fair dealings with their works, TPMs notwithstanding.

It is also significant that the scope of a user's right cannot be clearly delineated or universally applied. The legal analysis necessary to determine whether a particular use can be considered fair dealing in a particular instance is a complex one that involves a contextual examination of the use and user, and the balancing of multiple factors from the economic impact of the use to the alternatives available to the user. ${ }^{22}$ TPMs are not capable of performing such an analysis, and as such, are not capable of permitting individual access for fair dealing purposes or permitting fair dealings per se (even in the unlikely event that such a result were sought).

The effect of a TPM is thus to prevent the kinds of activities that are recognized, within the realm of copyright policy, to be deserving of protection from private owner interests, and to be central to the balance that copyright must strike. Simply put, TPMs deny users the ability to exercise their rights and thereby tip the balance away from users and the public interest. Here, again, it may be argued that a TPM-free version of a protected work will typically be available for anyone who wishes to deal fairly with it. And so it is worth re-emphasizing that, from a policy perspective, it is not satisfactory to restrict fair dealings to technologically inferior versions of copyright works (Bechtold, 2004, p.363). Beneficiaries of copyright exceptions, like rightholders, should be able to enjoy the opportunities presented by digital technologies, and should be free to engage with cultural resources in the technological environment in which they are situated.

While IP policy-makers, courts and commentators struggle to define and defend the fair dealing doctrine, their efforts are increasingly undercut by technological capabilities that leave such deliberations all but moot. Acts permitted in relation to owned content-users' rights to read, listen, research, study, criticize, transform - can be prevented by the use of TPMs, and would be 
effectively rendered unlawful by proposed anti-circumvention provisions. To extend legal protection to TPMs in a manner that fails to guard the contours of fair dealing from technological encroachment is thus to undermine the social goals of the copyright system and to relinquish the policy balancing act performed in their name.

\section{IN PURSUIT OF PRESCRIPTIVE PARALleLISM}

\section{A. Preserving the Copyright Balance}

The principle of "prescriptive parallelism" was articulated in a 2007 article by US commentators Jerome Reichman, Graeme Dinwoodie and Pamela Samuelson, to "convey the notion that the traditional copyright balance of rights and exceptions should be preserved in the digital environment" (Reichman et al., 2007, p. 1042). The principle captures the general normative position that "a technological adaptation, namely, the application of TPMs, should not alter the balance that existed under default rules of copyright law with respect to the enjoyment of exceptions and limitations" (Reichman et al., 2007, pp. 1041-2). The intuitive appeal of this position is quite evident, and nicely captured in the following words of Henning Wiese (2002):

[W] hilst on the one hand copyright holders will have a justified interest in regaining control over the publication/dissemination of their works, users will have an equal interest in retaining in the digital environment roughly the same fair use defences. In essence, society as a whole-including copyright owners and copyright work users-will wish to retain roughly the same copyright balance in virtual reality that has served all parties involved so well in the past, the 'real reality' (p. 147).

The problem, of course, is that the principle of prescriptive parallelism presents us with a challenge that, while conceptually clear, will be exceptionally hard to meet on a practical level. As Kerr and his co-authors rightly warn, "[t]he ensuing policy issue is not merely a question of copyright's ability to balance but also one of technology's power to control" (Kerr et al., 20022003, p. 38). This is the challenge that now presents itself to policy-makers and the Canadian copyright system: how can copyright's complicated balancing act continue to be performed in any meaningful way when the technological environment is increasingly one of absolutesabsolute freedom versus absolute control? More fundamentally, how can the law maintain its role as the guardian of this metaphorical balance when its prescriptions are increasingly extraneous to the actions and actors that it purports to influence?

Admittedly, a commitment to the principle of prescriptive parallelism presents at least as many questions as answers. Nonetheless, in the context of digital copyright reform, the principle could prove exceptionally useful: it offers a jumping-off point (a normative claim); it provides a sense of direction (a guidepost by which to chart progress); and it establishes an ideal (a goal against which to measure purported success). It is also difficult to refute, unless one is willing to openly take issue with the foundational principles that underlie our existing institutional 
structures. In this sense, the principle wields some political clout. It may be that genuine prescriptive parallelism is an unattainable aspiration, but to admit as much is not to undermine its normative significance; it is a goal at which we should aim, and one that we should be determined to achieve to the greatest extent possible.

\section{Retaining the Balance through Inaction?}

One route towards maintaining copyright's traditional balance may be to simply leave the law as it is, for now at least; we can continue to apply and enforce traditional copyright norms while technology and the marketplace evolve on their own terms. In this way, the law will perform its traditional balancing act within its shrinking domain of influence. There are many commentators and stakeholders who adhere to this vision, and I am tempted to count myself among them. When it comes to the law, after all, there are worse things than irrelevance. As Jessica Litman has argued, there is simply no reason for us to assume that copyright laws should determine the most basic "rules of the game" in cyberspace (Litman, 2001, p. 28). Indeed, their complexity, inaccessibility and limited focus make them quite inapposite to the task:

Copyright law has a narrow focus. It has never paid attention to a whole host of important interests that have traditionally informed our information policy, and copyright analysis turns out to have very little room in it to do so.

In addition to free speech concerns, information policy takes account of issues related to equity, competition, ensuring a diversity of viewpoints, securing ready and affordable access to important sources of information privacy-all issues that are at best tangential to copyright law and in some cases wholly alien (Litman, 2001, p. 30).

As Litman argues, the significance of these limitations is far greater in a context where copyright law is expected to govern, not just the activities of commercial and institutional entities as it has traditionally done, but the everyday behaviour and interactions of members of the general public.

Litman further cautions that the structure and involvement of the copyright community in the copyright reform process make it "difficult to prevent foolish approaches to new technology" (Litman, 2001, p. 22). Reforms in response to technological advances are typically fought out by industry stakeholders determined to regain old benefits enjoyed before the technological advance, while retaining any new benefits that the technology may afford (Litman, 2001, p.22). Notably, amongst such "foolish" approaches, Litman appears to include the enactment of anticircumvention laws in the US Digital Millennium Copyright Act (DMCA). ${ }^{23}$

In a similar vein, Laura Murray has observed "the near-perfect match between the rhetoric of wonder and panic at digital technologies and the hyperbole and hysteria that greeted the telegraph, the telephone, the television, and the photocopier" (Murray, 2005, p. 26). Citing Litman, Murray agrees that such historical precedents sound a cautionary note about the swift implementation of new laws in response to new technologies. History reveals that rapid legal 
responses risk becoming dated and "loophole-ridden" legal regimes, failing to reflect our evolving understanding of the new technology and the role that it will come to occupy in our market place and society (Murray, 2005, p. 26). Kerr and his co-authors issue a similar exhortation, urging:

$[U]$ ntil the market for digital content and the norms surrounding the use and circumvention of TPMs (and their implications for that market) become better known, it is simply premature to try to ascertain what the appropriate practical legal response should be....[M]aking policy decisions without such knowledge could result in great harm to the public interest (Kerr et al., 2002-2003, p. 76). ${ }^{24}$

This position is consistent with the general principle of technological neutrality, which stands against the implementation of technology-specific norms that are unlikely to maintain their relevance and applicability as technologies inevitably evolve (Kerr et al., 2002-2003, p. 81). ${ }^{25}$ Indeed, some argue that the evolution of technology has already rendered the TPM-protection debate out-dated. As consumers become increasingly cognizant of, and resistant to, the limitations imposed by digital locks and other rights management technologies, the argument goes, market forces should gradually increase demand for free as opposed to controlled content, with content providers necessarily reacting to such market dictates. Apple's decision to sell Digital Rights Management (DRM)-free music through the iTunes store is commonly cited in support of this thesis. ${ }^{26}$ The problem is that it assumes a well-functioning competitive market for DRM-protected and DRM-free content, and minimizes the impact of network and lock-in effects, information asymmetries and other causes of market failure (Bechtold, 2004, p. 362). Whatever degree of faith we are willing to place in such market forces over time, we can likely agree that TPMs and DRM technologies look set to stay with us for a while.

While inaction may preserve the internal coherence and "balance" of the copyright system, its capacity to achieve an actual balance in our overall information system is undermined when its prescriptions become divorced from common practice. Inaction could thus result in the marginalization of copyright and its normative significance as technology and technological selfhelp establish the norms of behaviour online.

\section{Regaining the Balance through Legislative Reform}

If we assume that copyright should play a significant role in regulating cultural practices in the digital environment-and we accept that this is good policy as opposed to an act of hubris on the part of copyright lawyers (compare to Litman, 2001, p. 30)-then it seems reasonable to assert that some degree of legal reform is necessary to respond to technological changes that have rendered certain traditional copyright assumptions outmoded. This logic suggests an alternative route towards maintaining copyright's balance while also striving to preserve its relevance: namely, amending existing laws to better regulate the use of technology and the digital marketplace in a way that can achieve prescriptive parallelism in practice. 
When anti-circumvention laws are rationalized as "enhanced legal protection for copyright owners in light of enhanced copying capacity" (Reichman et al., 2007, p. 1042), the implicit assumption is that a further layer of protection is necessary to reinstate copyright's balance in the face of new technologies. ${ }^{27}$ In pursuit of this balance, however, adjustments may also be needed to the legal rights of copyright users in light of the availability, application and legal protection of TPMs (Wiese, 2002, p. 147). If we accept that, as a matter of substantive principle, "the application of TPMs should not alter the balance of rights between copyright owners and users," then it ought to follow that "all uses privileged under traditional copyright principles should continue to be privileged in an era of digital rights management" (Reichman et al., 2007, p. 1045). This assertion is consistent with (and arguably mandated by) the recognition of exceptions to authors' rights as integral to the copyright system. As such, any new digital copyright regime that is rationalized in terms of reinstating copyright's balance in the digital era must offer a comprehensive regulatory approach-one that establishes a "symmetric" environment in which the legitimate interests of both rightholders and users are protected (Bechtold, 2004, p. 363).

Reichman and his co-authors argue that, if the principle of prescriptive parallelism is to be respected in the face of TPM protections, "users need a mechanism by which to vindicate their rights and to secure the certainty required to engage in creative activity privileged under traditional copyright principles" (Reichman et al., 2007, p. 1045). In pursuit of prescriptive parallelism in Canada, it is suggested that any new anti-circumvention provisions must also establish a mechanism by which users can vindicate their rights, exercise their privileges, and feel safe in the knowledge that they will not incur liability for doing so. Admittedly, such a mechanism could prove complex and costly to implement, but we must be willing to assume these costs and tackle these complexities if we go down the path of prohibiting circumvention while maintaining a genuine commitment to copyright's balance. (And if such mechanisms are too complex or costly, we may have to reconsider the wisdom of taking that path).

\section{B. Legislative Measures and Mechanisms to Vindicate User Rights}

With a view to identifying the possibilities, promises and potential pitfalls of a new Canadian TPM protection regime, this section will canvas some approaches taken in other jurisdictions towards the reconciliation of TPM protection and copyright limitations, and the extent to which these approaches have been able to meet the principled demands of prescriptive parallelism. This will provide the comparative perspective necessary for us to proceed, in the next section, towards recommendations for Canadian reform.

\section{Looking to the United States: The DMCA}

Perhaps the weakest approach to safeguarding the traditional privileges of users and the public in the face of TPM protection is found in the now infamous US DMCA. ${ }^{28}$ The controversial anticircumvention provisions in this Act offer a level of protection for TPMs significantly beyond that required by the WIPO treaties. The DMCA prohibits the circumvention of TPMs that control 
access to a protected work (regardless of whether such access results in copyright infringement) ( $\$ 1201(\mathrm{a})(1)(\mathrm{A})$ ), and forbids the manufacture, distribution, and importation of circumvention tools (including tools that circumvent both "access-contol" measures and use- or "rights-control" measures) ( $\$ 1201(\mathrm{a})(2)$ and $\left(\S 1201\right.$ (b)). ${ }^{29}$ Because protection does not attach to use-control measures, it has been suggested that fair use is not per se affected by the anticircumvention measures. Indeed, $\$ 1201(c)(1)$ explicitly states that, "[n]othing in this section shall affect rights, remedies, limitations, or defenses to copyright infringement, including fair use, in this title." Of course, the reality is that access to a work is a prerequisite of fair use, and access to a circumvention tool may be a prerequisite of access to a TPM-protected work. The effect of the access-control circumvention prohibition and circumvention device prohibitions is the practical restriction of otherwise lawful fair use activities in relation to TPM-protected content.

The DMCA anti-circumvention rules are subject to a set of seven narrow and hard-fought exceptions $^{30}$ that shield circumvention activities from liability in specific circumstances, including, for example: non-profit libraries making acquisition decisions (\$1201 (d)); governmental actors conducting national security activities ( $\$ 1201(\mathrm{e})$ ); and encryption researchers identifying vulnerabilities in encryption technologies $(\S 1201(\mathrm{~g})) .{ }^{31}$ Litman has rightly accused these exceptions of being "cast in prose so crabbed and so encumbered with conditions as to be of little use to anyone who doesn't have a copyright lawyer around to explain which hoops to jump through" (Litman, 2001, p. 31).

In addition to the specified exemptions, the DMCA authorizes the Librarian of Congress, in consultation with the Register of Copyright, to assess the impact of the circumvention ban on traditional fair use practices and, if necessary, to issue rules exempting certain users of certain categories of works from the ban $(\S 1201(\mathrm{a})(1)(B)-(D))$. The 2006 round of this triennial rulemaking proceeding yielded temporary exemptions for six narrowly defined classes of works. ${ }^{32}$ However, such exemptions are not permitted to extend to the prohibition on circumvention technologies (device controls), with the consequence that, "[a]s a practical matter,...any exemptions ultimately declared will have very limited utility; self-evidently, most users will be unable to exercise their circumvention rights unless they are provided with the tools to do so" (Burk and Cohen, 2001, pp. 49-50). Moreover, by granting such power to an administrative agency, this procedure has the clear and apparently intended effect of reducing the role of the courts and the relevance of fair use in the digital age (see Herman and Gandy Jr., 2006). ${ }^{33}$ The prospective creation of exemptions based on "classes of works" turns on its head the traditionally purposive, use-based and post hoc application of fair use by the courts (Herman and Gandy Jr., 2006, pp. 143-4). The clear impoverishment of fair use effectuated by the DMCA led David Nimmer to suggest that the Act was "a conscious contraction of user rights" (Nimmer, 2000, p. 675; cited in Herman and Gandy Jr., 2006, p. 187).

Since the enactment of the DMCA, a number of incidents and cases have revealed that this apparent threat to fair use activities is more than hypothetical. ${ }^{34}$ Perhaps most notable is the case of Universal City Studios v. Remeirdes, ${ }^{35}$ which concerned a software program, DeCSS, posted online by the defendant, which could be used to crack the Content Scramble System 
[CSS] on commericial DVDs, allowing users to copy and manipulate a DVD's content. In an amicus brief, Professors Benkler and Lessig described CSS as "a device that makes fair and otherwise privileged uses of digitized materials practically impossible" (Benkler and Lessig, 2001). The defendant challenged the constitutionality of the DMCA, arguing inter alia that it unduly obstructs the "fair use" of copyright materials. The US District Court held that fair use was not a defence to violations of the DMCA and issued injunctions. Upholding this decision, the US Court of Appeals dismissed the appellant's constitutional claim as "extravagant." appellant was not personally engaged in any fair use of copyright materials, and the court was unimpressed by the argument that the devices were necessary for others to make fair uses of CSS protected content. Indeed, the Court was not persuaded that CSS prevents fair uses, not least because "[f]air use has never been held to be a guarantee of access to copyrighted material in order to copy it by the fair user's preferred technique or in the format of the original. ${ }^{37}$

Notably, the CSS has proved to be "the single most controversial TPM scheme considered in the triennial rulemaking proceedings" under the regulatory powers granted to the Librarian of Congress (Hermann \& Gandy, 2006, p. 187-8.). Despite hundreds of calls for exemptions and many documented harms to fair use, "it remains illegal to circumvent the access controls on a legally purchased DVD, even for purposes such as playing it on one's home machine or using fifteen seconds of footage for scholarly commentary" (Herman and Gandy Jr., 2006, p. 188). An exemption added after the 2006 rulemaking proceeding was limited to:

audiovisual works included in the educational library of a college or university's film or media studies department, when circumvention is accomplished for the purpose of making compilations of portions of those works for educational use in the classroom by media studies or film professors. ${ }^{38}$

Such a limited exemption serves only to underscore the inadequacies of the rulemaking procedure, and to reveal the virtually insurmountable burden imposed of those who seek exemptions from the circumvention prohibitions under the DMCA.

\section{Looking to Europe: The EU Copyright Directive}

The European Union followed the United States' lead when it issued its Copyright Directive of 2001, requiring member states to enact broad anti-circumvention prohibitions against all acts of circumvention and the trafficking of circumvention devices and services, and thereby far exceeding the scope of TPM protection demanded by the WIPO treaties. ${ }^{39}$ The Directive does not contain built-in exceptions such as those in the DMCA, but instead addresses the interaction between TPM protection and user exceptions in Article 6(4), which states: "in the absence of voluntary measures taken by right holders... Member States shall take appropriate measures to ensure that right holders make available to the beneficiary of an exception or limitation provided for in national law...the means of benefiting from that exception or limitation." 
Article 6(4) is significant-perhaps even "rather revolutionary" (Dusollier, 2003, p. 52)-to the extent that it attributes a positive dimension to copyright exceptions, recognizing the need to facilitate (as opposed to merely permit) the exercise of exceptions to owners' rights. Reichman and his co-authors identify, within this provision, an important "normative commitment to ensuring that certain public interest uses can be made of technically protected works" (Reichman et al., 2007, p. 984). As an apparent attempt to maintain the balance of copyright in the face of TPM protection, Article 6(4) seems premised to some degree on the principle of prescriptive parallelism (Reichman et al., 2007, p. 1042). ${ }^{40}$ However, as these authors and many others have noted, its actual prescriptions fall well short of realizing this ostensible principle (see Hugenholtz, 2000; Dusollier, 2003; Riechman et al., 2007, pp. 1041-4).

The provision employs a "fair use by mandate" approach ${ }^{41}$ by leaving it to copyright owners, in the first instance, to find a solution to the tension between TPMs and copyright exceptions. Only in the absence of "voluntary measures" (the nature and scope of which is left undefined) does the State's obligation arise. ${ }^{42}$ This approach actually reinforces the primacy of the private ordering model supported by TPMs, which is further evidenced by the decision to exclude from the application of Article 6(4) "works made available to the public on agreed contractual terms in such a way that members of the public may access them from a place and at a time individually chosen by them." 43 This effectively exempts on-demand services from the obligation to safeguard user exceptions; rightholders who make their works available online on agreed contractual terms (obviously an important and growing digital distribution model) can presumably continue to prevent users from benefiting from copyright exceptions (Akester, 2009, p. 17). ${ }^{44}$

The impact of Article 6(4) is further lessened by its restriction to beneficiaries with "legal access to the protected work." Only users with prior lawful access to the work are empowered to exercise exceptions, but there is apparently no obligation for owners to grant access to such users. Consequently, the safeguard provision does not appear to shield lawful uses from the effects of access-control TPMs.

Finally, but crucially, Article 6(4) applies only to seven specified (and seemingly arbitrary) exceptions out of the twenty-three permitted exceptions listed in Article 5 of the Directive. ${ }^{45}$ Notably excluded from the application of Article 6(4) are exceptions for parody and news reporting-both activities that we may typically associate with fair use rights, and both exceptions that are widely understood to reflect a concern with fundamental freedoms of speech and the press (Dusollier, 2003, p. 53). Indeed, even with regard to the seven exceptions that are listed, Article 6(4) operates only to safeguard the benefit of exceptions that are "provided for in national law." Member states are permitted, but not required, to enact the enumerated exceptions, with the result that Article 6(4) "make[s] mandatory the safeguarding of exceptions but not their enactment" (Dusollier, 2003, p. 53). ${ }^{46}$

While, conceptually speaking, Article 6(4) of the EU Copyright Directive was both novel and laudable, its potential to achieve prescriptive parallelism has been significantly undermined by these various textual and practical limitations. To the extent that it purports to protect the 
public values embraced by copyright limitations, it is a "toothless tiger" (Bechtold, 2004, p. 379). Beneath the ostensible promise of balance, the EU copyright regime supports private ordering by rightholders through the use of TPMs that restrict otherwise lawful uses of digital content. ${ }^{47}$ Predictably, then, national implementations of the EU Copyright Directive have produced a wide variety of different approaches to the problem of TPM protection and copyright exceptions, which have largely failed to adequately safeguard public uses of TPMprotected content or to achieve a parallel balance of interests in the digital realm (Reichman et al., 2007, p. 984).

The Directive permits member states to pursue a "wait-and-see" strategy, taking no immediate steps to ensure that the beneficiaries of exceptions can actually enjoy them (Gasser, 2006, p. 77). Austria, for example, has enacted no exceptions to its broad anti-circumvention provisions, opting instead to assume that voluntary and market-driven measures will adequately enable the exercise of existing exceptions, and empowering the Minister of Justice and a government department to report to Parliament recommending legislative measures if such proves not to be the case. The Czech Republic and the Netherlands have similarly left it to the executive power to take appropriate measures to safeguard user exceptions only if and when necessary (Commission of the European Community, 2007; see also Gasser, 2006, p. 77). Other member states (including Finland, Denmark, Estonia, Greece, Lithuania, Slovenia, and Hungary) have opted to introduce mediation or arbitration proceedings for the beneficiaries of exceptions where private negotiations fail to facilitate permitted uses. A third approach, taken by Germany, Ireland, Spain, Luxembourg and Belgium, has been to establish a right of recourse to the courts for would-be users denied the means of benefiting from exceptions. ${ }^{48}$ Finally, other member states have established an administrative complaints procedure.

In the United Kingdom, the new section $2962 \mathrm{E}^{49}$ allows persons who are prevented by TPMs from performing an otherwise permitted act to file a complaint with the Secretary of State. The Secretary of State, acting through the Patent Office, will investigate whether any voluntary measure or agreement exists in relation to the work and, in the absence of such, may issue a written direction requiring the copyright owner to ensure that the complainant can benefit from the permitted act. Failure to comply is an actionable breach of statutory duty.

In France, the slow transposition process ultimately saw the establishment, in 2007, of an entirely new administrative body, the Autorité de regulation des measures techniques de protection, or ARMTP. ${ }^{50}$ This independent regulatory agency represents a novel governance structure specifically designed to address the challenges of TPMs in the information economy (Winn and Jondet, 2009). In the absence of voluntary measures, cases may be submitted to the ARMPTP by consumers, the beneficiaries of exceptions, or their representatives. The agency will decide the legality of the use of a TPM in the specific case, subject to appeal, and may order rightholders to take necessary steps to allow the exception to be exercised and impose financial penalties for failure to comply.

On the basis of this brief summary, it is evident that the Directive has failed to produce significant harmonization in this area, but also that it has thus far failed to achieve prescriptive 
parallelism to any significant degree. Even in those member states that did opt to enact legislative safeguards for user exceptions, the execution of the exception regime is typically cumbersome and impractical for the would-be beneficiaries (Wang, 2006, p. 243; citing Midgley, 2002). Where beneficiaries are empowered to seek injunctive relief from the courts, or even to initiate mediation, they are invited to embark upon a potentially costly, prolonged, and onerous course of action that is unlikely to make sense for the average user. Mediation solutions reduce the exercise of permitted acts to a matter for negotiation or rightholder authorization not dissimilar to that required in respect of restricted acts (Dusollier, 2003, p. 73). Administrative solutions may be even more burdensome: in the United Kingdom, for example, rightholders have no pre-existing obligation to facilitate the exercise of permitted acts; the Secretary of State has no obligation to order the rightholder to do so; the complainant has no right to appeal the Secretary's decision; and failure to comply with an order merely establishes a right of action, making the pre-requisite complaint process little more than an additional administrative hurdle for the would-be beneficiary. While the enforcement powers of the French ARMPTP, together with the right to appeal its decisions, make it perhaps the most interesting initiative, the administrative burden imposed on users may nonetheless represent a significant barrier to the exercise of permitted acts. In the absence of efficient, effective, and readily accessible enforcement structures throughout the EU member states, the apparent promise of Article 6(4) is far from being fulfilled.

\section{Beyond Europe: New Zealand's Example}

Beyond Europe, New Zealand offers an interesting example of a novel solution to the problematic interaction of TPM-protection and copyright exceptions. The Copyright (New Technologies) Amendment Act 2008 prohibits the distribution of circumvention devices, services and information where it is known that such will, or is likely to, be used to infringe copyright (section 226A). Notably, the prohibitions do not extend to acts of circumvention per se, and nor do they protect pure access-control TPMs. In addition to the careful circumscription of anti-circumvention rights, the Act includes positive measures to protect beneficiaries of copyright exceptions. First, it explicitly states that the rights granted to the issuer of a TPM work "do not prevent or restrict the exercise of a permitted act" (section 226D(1)) and that "[n]othing in this Act prevents any person from using a TPM circumvention device to exercise a permitted act" (section 226E(1)). Secondly, it introduces new provisions enabling a person who wishes to carry out a permitted act to seek assistance from the copyright owner and/or a qualified person in order to circumvent a TPM (section 226E(2)). ${ }^{51} \mathrm{~A}$ "qualified person" means a librarian of a prescribed library, an archivist of an archive, an educational establishment, or any person specified by the Governor-General by Order in Council under a new regulation-making power (section 226D(3)). By empowering certain people to offer circumvention services, and by enabling these people to be lawfully supplied with circumvention devices, the approach taken by New Zealand goes some way towards ensuring that non-infringing activities in respect of TPM-protected works are not merely permitted, but also practicable. ${ }^{52}$ How the system will work in practice remains to be seen. 


\section{Anti-circumvention and the Fate of Fair Dealing in Canada: Problems and PROPOSALS}

As countries around the world develop and implement new legislative and regulatory schemes for protecting TPMs, the practical and political implications of TPM protection, and the challenges of integrating user and public interest exceptions into these protective schemes, become increasingly clear. The good news, however, is that Canada is now in an excellent position to benefit from the lessons that have been learned elsewhere, and to choose its path into the digital future with the benefit of other nations' hindsight. In this section, I will provide a brief overview of the two "false starts" that Canada has made in the race to introduce anticircumvention protection. I will go on to suggest possible solutions to the current impassewhich will also serve as a critique of Canada's previous attempts to introduce TPM protectionand canvas some available means by which we may yet achieve prescriptive parallelism, to a greater or lesser degree.

\section{A. TWo FALSE StARTS}

In a law reform process that began back in 2001, Canadian Heritage and Industry Canada are currently formulating what will be the third iteration of proposed anti-circumvention legislation, which will follow on the heels of two previous Bills-and two starkly different approaches to the protection of TPMs. Bill C-60, which represented the first attempt to introduce anti-circumvention provisions, was developed under and swept aside with Canada's Liberal government. Section 34.02(1) of Bill C-60 sought to establish legal protection for $\mathrm{TPMs}^{53}$ :

34.02 (1) An owner of copyright in a work, a performer's performance fixed in a sound recording or a sound recording....are, subject to this Act, entitled to all remedies...that are or may be conferred by law for the infringement of a right against a person who, without the consent of the copyright owner..., circumvents, removes or in any way renders ineffective a technological measure protecting any material form of the work, the performer's performance or the sound recording for the purpose of an act that is an infringement of the copyright in it or the moral rights in respect of it or for the purpose of making a copy referred to in subsection 80(1). [Emphasis added].

The effect of this provision would have been to make it an infringement to circumvent a TPM, but only if this were done for the purpose of an act constituting infringement of the copyright in the underlying work. ${ }^{54}$ This suggests that circumvention for the purposes of fair dealing would have remained lawful (Geist, 2005, p. 242). Section 34.02 also contained, in subsection (2), a provision establishing the same remedies against a person who "offers or provides a service to circumvent, remove or render ineffective a technological measure protecting a material form of the work," where that person "knows or ought to know that providing the service will result in 
an infringement of the copyright or moral rights." Although this section would have left some uncertainty with regard to the degree of knowledge required, ${ }^{55}$ the legislative intent was clearly to tie liability for the provision of circumvention services to actual acts of copyright infringement. Moreover, the bill established no legal limitation on circumvention devices or technologies (Geist, 2005, p. 242).

Bill C-60 was thus compliant with the WCT, but in a way that recognized-and generally took advantage of-the limits and flexibility of Article 11 to minimize the potential impact of anticircumvention laws beyond that of existing copyright norms. By linking circumvention liability to copyright infringement liability, it proposed an additional level protection for rightholders without substantially widening the net of liability to catch activities that would have been lawful in the absence of these additional protections. In doing so, the bill was apparently intended to maintain the balance between owners and users struck by traditional copyright norms, and to avoid increasing the scope of rights connected to copyright ownership.

Bill C-60 was nonetheless vulnerable to the criticism that traditional copyright limits and exceptions were not explicitly protected or positively safe-guarded against the operation of the anti-circumvention provisions, never mind the operation of TPMs themselves. To the existing fears of copyright infringement suits and the curtailments effected by the proliferation of TPMs, Bill C-60 would have added the risk of liability for TPM circumvention-a further threat with which to chill uses of protected content. Bill C-60 did not offer to protect users and the public from the effects of TPMs and anti-circumvention liability (Geist, 2005, pp. 248-9). ${ }^{56}$ In this sense, the bill offered nothing to proactively maintain the copyright balance against the disruptive impact of the widespread use of TPMs.

While the fate of C-60 was sealed with the fall of the Liberal government, the drive towards new legislation continued under the new Conservative government. Whereas Bill C-60 tread a moderate path with regard to new anti-circumvention provisions, Bill C-61, tabled in 2008, was designed to offer "stronger legal protection for T[P]Ms or digital locks applied by rights owners to digital works" (Government of Canada, 2008a). While this bill was also destined to die on the order paper when a federal election was called in September 2008, it may be a harbinger of what we can expect in any future copyright reform bill brought under the re-instated Conservative minority government, which continues to proclaim its commitment to new legislation "to modernize Canada's copyright laws and ensure stronger protection for intellectual property" (Government of Canada, 2008c).

In contrast to the relatively succinct TPM provisions of Bill C-60 (which amounted to one section with three sub-sections), C-61 contained thirteen complex sections with innumerable subsections prescribing the broad protection of TPMs and the narrow limits thereto. Notably, Bill C-61 offered pure access-control TPMs the same protection as TPMs that restrict protected uses of underlying works. ${ }^{57}$ The bill crossed another important line by prohibiting, in addition to circumvention activities and services, devices or technologies that permit the circumvention of TPMs. ${ }^{58}$ Whether a particular technology would caught by this prohibition was to be 
determined in light of its primary purpose ${ }^{59}$ commercial significance ${ }^{60}$ or the manner in which it is marketed. ${ }^{61}$

Bill C-61 set out specific exceptions to circumvention liability-as well as numerous exceptions to these exceptions-relating to law enforcement or national security (section 41.11), computer program interoperability (section 41.12), encryption research (section 41.13), the collection/communication of personal information (section 41.14), the security of computer systems/networks (section 41.15), persons with perceptual disabilities (section 41.16), and ephemeral recordings by broadcast undertakings (section 41.17). Thus, for example, a person circumventing a TPM for the purpose of encryption research would escape liability only if: it would not have been practical to carry out the research without circumventing the TPM; s/he lawfully obtained the protected work; s/he informed the copyright owner who applied the TPM (presumably, that s/he would be circumventing the TPM for research purposes); and s/he did nothing in relation to the underlying work that would constitute an infringement of copyright (section 41.13).

The Bill sought to establish the power for the Governor in Council to make additional regulations to create further specific exceptions where technological measures "would unduly restrict competition in the aftermarket sector in which the technological measure is used" (section 41.2(1)). It envisaged the possibility of further regulations restricting liability for acts of circumvention (but, notably, not for liability relating to circumvention services or technologies) to be made in consideration of an open list of factors, including: whether the prohibition against acts of circumvention could adversely affect authorized uses; whether it would adversely affect criticism, review, news reporting, commentary, teaching, scholarship or research that could be made or done in respect of the work; whether it could adversely affect the market for the underlying work; and the work's commercial availability (section 41.2(2)(a)). An interesting provision contemplated the possibility of a positive claim against copyright owners, empowering the Governor in Council to make regulations requiring owners to provide access to a protected work to persons entitled to benefit from any limitations established in light of these factors (section 41.2(2)(b)). ${ }^{62}$

Overall, Bill C-61 failed to reflect the lessons readily drawn from the experiences of the United States and Europe: it sought to establish broad anti-circumvention rights covering devices and services, access- and use-control measures, and to do so without tying these rights to copyright infringement; it set out numerous complex exceptions with no general "fair circumvention" exception; it neglected even to offer lip-service to the preservation of fair dealing rights comparable to statements found in Article 6(4) of the E.U. Directive or section 1201(a) of the DMCA; it offloaded the responsibility for carving out any more exceptions on the Governor in Council, without making clear on what basis such exceptions would be regulated, on whose request, and subject to what evidentiary burden; ${ }^{63}$ and it established no positive obligations for content providers, leaving any such obligations to be created through regulation, and only in respect of any new exceptions made under this regulatory power. It is also significant that "new" exceptions that were included in the bill-exceptions for format and time shifting, for example-were made subject to non-circumvention provisos that would render them 
redundant in the face of TPMs, ${ }^{64}$ thereby privileging TPMs over the public policy goals that the exceptions were ostensibly designed to serve.

Bills C-60 and C-61 thus took practically polemic approaches to the enactment of anticircumvention provisions. While the former bill would have established a new level of protection for copyright owners and thereby more than satisfied the requirements of the WIPO Treaties, it would have done so at relatively minimalist level, essentially duplicating the existing scope (if not the basis) of liability under existing copyright norms. In contrast, Bill C-61 went significantly beyond the protections required by the treaties. While C- 61 included limitations not articulated in C-60, these did not amount to a broad or principled restriction of the scope of anti-circumvention rights; rather, the complexity and rigidity of these narrowly constructed exceptions suggested only a grudging willingness to make minimal carve-outs to far-reaching prohibitions. In this way, Bill C-61 failed to reflect the centrality of fair dealing and the public domain in copyright policy, treating them instead as marginal elements of the existing system that could be reduced or eliminated to better protect owner interests in the digital environment. In doing so, it threatened to significantly upset the copyright balance established in Canada and articulated by our Supreme Court.

In choosing its approach to the legal regulation of TPMs, Parliament is not constitutionally bound to follow the conclusions of the Supreme Court or to pursue the goals of the copyright system as defined by the Court-but one might expect that Parliament would be duly influenced by the reasoning of the highest court of the land, and would share its commitment to achieving a balanced copyright system (Murray, 2005, p. 652). As Geist explains, "[b]y sending a clear message about its support for a fair copyright balance [in Théberge], the Supreme Court has indirectly provided the most important submission on the current digital copyright reform consultations" (Geist, 2002; cited in Kerr et al., 2002-2003, p. 41). Since 2002, the Court has reiterated, expanded on and applied its vision of balance-making further indirect contributions to a consultation process that continues today. And, indeed, the government claims to have been guided, in the copyright reform process, by the principle that "the rights of those who hold copyright must be balanced with the needs of users to access copyright works" (Government of Canada, 2008). But Bill C-61 did not reflect this principle in any meaningful way: to take the principle of balance seriously would be to embrace the goal of prescriptive parallelism, and to ensure that fair and lawful dealings are permitted, encouraged and actively facilitated under any digital amendments to the copyright regime.

\section{B. Proposals for Canada: In Pursuit of Prescriptive Parallelism}

In designing Canada's digital copyright policy, the first and fundamental question to be asked is whether prescriptive parallelism can be embraced as an appropriate substantive goal of reform: is the overarching aim of copyright reform to achieve roughly the same balance of interests in the digital realm as copyright has traditionally maintained in the analogue world? The digital shift alters the practical and pragmatic considerations at play, but does it alter the normative objectives of our copyright system, or the social values that inform it? If we can agree on the 
validity of prescriptive parallelism as a goal, we can approach reform by asking how this goal can be achieved to the greatest possible extent.

The simplest solution-and in my opinion, the best solution, at least for now-would be to resist the pressure to enact anti-circumvention legislation. As Kerr and his co-authors advised in 2002 , the "[b]est strategy for maintaining a balanced copyright law is to take an approach that best preserves the status quo..." (Kerr et al., 2002-2003, p. 82). While owners and distributors would continue to use TPMs to erect fences around content, these fences would not be actively encouraged-or "electrified" - by the creation of legal prohibitions.

In those jurisdictions that have already enacted anti-circumvention laws, the swift and frequent calls for further amendments to correct these new regimes add credibility to the claim that such laws may still be premature and rife with unintended consequences. The United States has seen several attempts to amend the DMCA to better reflect the limits of control consistent with traditional copyright policy and the Constitution. ${ }^{65}$ Recent reports in Europe have identified serious concerns with the EU Copyright Directive and its implementation by member states (Akester, year; Gowers, 2007; Guibault et al., 2007). As other legislatures come under increasing pressure to correct perceived mistakes in their digital copyright laws, Canadians should take some comfort in the possibility that inaction may yet be proved to have been the best course of action. In Israel, which, like Canada, has signed but not ratified the WIPO Treaties, a "wait-and-see" approach has apparently found favour; recent amendments to the copyright legislation simply did not include the introduction of anticipated TPM protection measures (see deBeer, 2009, p. 6; Israel's Copyright Act 2007). An official statement by the Government of Israel explained this inaction with reference to the widespread criticism of TPMs and doubts as to their continued commercial relevance (Government of Israel, 2008; cited in deBeer, 2009, p. 7, note 22). The Government of Israel was correct to assert that, absent an international obligation to enact legal protections for TPM, other nations have no legitimate basis for complaint against a nation that opts to "wait and see" (Government of Israel, 2008, pp. 8-9).

Even this approach, however, leaves unanswered the question of how to actively accommodate fair and lawful uses of protected works to ensure the appropriate balance between owners' rights and the public interest. The protection of TPMs may be unnecessary, but it may still be that the public needs legal protection from TPMs (Kerr et al., 2002-2003, p. 79). In this sense, the absence of anti-circumvention laws is not a genuine "solution" to problem of reconciling TPMs and user rights; a balanced copyright system may require appropriate steps to be taken to protect permitted acts. But from a political perspective, the government is less likely to face pressure to create a system to safeguard lawful uses of protected content if it simply declines to enter the fray. Rather than buttressing the interests of either owners or users, the use and abuse of technological measures would be left to run its course subject to existing legal norms. Particularly in light of the costs and complexities of the alternatives canvassed below, this approach surely has much to recommend it. 
If the Canadian government chooses to include anti-circumvention provisions in the next reform bill, the foregoing discussion suggests some insights into the shape that these provisions should take. Most fundamentally, TPM protection should be carefully circumscribed to ensure minimum disruption to the existing copyright balance. Particularly if motivated by a primarily political desire to ratify the WIPO treaties, this means that Parliament should proceed in a way that minimally satisfies these treaties' requirements (Murray and Trosow, 2007, p. 205; Kerr et al., 2002-2003, p. 77).

One option that has received little consideration is the possibility of making the legal protection of TPMs subject to certain formalities. By establishing a new TPM registry at the Canadian Intellectual Property Office, for example, it would be possible to subject TPM protection to appropriate requirements, which could relate to the effectiveness and/or restrictiveness of the TPM for which protection is sought, and/or condition protection on the deposit of a TPM-free digital copy, or a "digital key" or decryption code (or even a guarantee that such will be made available to facilitate lawful uses on request). CIPO or the registrar would then be well placed to act as an independent intermediary in the resolution of access disputes. ${ }^{66}$

If Parliament prefers to proceed with automatic protection for TPMs, the original bill C-60 provides a decent example of what a minimalist approach might look like. In application, this approach would produce TPM protections that closely align with the existing rights of copyright owners, essentially reinforcing copyright proper by limiting unlawful circumvention to acts undertaken for purposes of copyright infringement. Consistent with this minimalist approach, protection would be afforded only to use-control TPMs. This could be achieved by defining technical measures in terms of their ability to inhibit or prevent infringing acts, as was done in Bill C-60, and ideally with the explicit exclusion of measures that control access to works for non-infringing purposes, as seen in the New Zealand legislation. ${ }^{67}$

Furthermore, a minimalist approach to TPM protection would not include device prohibitions. While a prohibition on the manufacturing and distribution of circumvention technologies would increase the ease and efficiency with which content providers could prevent circumventions, such technologies must be available to those who wish to access and use protected works in non-infringing ways. In $\mathrm{CCH}$, the Supreme Court denied the plaintiff copyright owners the easiest route towards preventing a widespread, potentially infringing activity because the result would have been to shift the copyright balance too far in favour of owners' rights, and to interfere with "the proper use of copyrighted works for the good of society as a whole" $(\mathrm{CCH}$, paragraph 41). The same considerations and commitment to balance ought to warn us away from the enactment of circumvention device prohibitions as a shortcut to restrict circumvention activities. Where a distributor of circumvention technologies ought to be liable for subsequent infringement by third parties, that person will incur liability for "authorizing infringement" under existing copyright norms. ${ }^{68}$

Should Parliament choose to take the alternative route of restricting circumvention devices, a reasonably balanced system would require a restrictive definition of technologies caught by the prohibition, which would not unduly impede the development and availability of dual-use 
technologies or technologies with substantial non-infringing uses. Certainly, any anti-device provision must apply only to those devices designed primarily for the purpose of circumventing TPMs, or those with no (or limited) commercial purpose beyond the circumvention of TPMs. It should also be stressed that device prohibitions would make even more pressing the need for an adequate mechanism or infrastructure to facilitate fair uses by making available to the public the means by which they could be carried out. ${ }^{69}$

Finally, any anti-circumvention provisions in Canada should operate "without prejudice" to the exceptions contained in the Copyright Act. Tying circumvention liability to copyright infringement goes part way to achieving this goal by implicitly permitting the lawful circumvention of TPMs for the purposes of fair dealing and other permitted acts. However, it would be preferable to see, in any new circumvention provisions, an explicit statement that circumvention is not prohibited when undertaken for lawful purposes including fair dealings.

In order to ensure that fair dealings and other permitted acts are not only lawful on the books but also possible in practice, a revised Copyright Act should establish positive obligations for rightholders to facilitate fair and lawful dealings with TPM-protected works. ${ }^{70}$ This could take the form of a basic requirement-similar to that found in the German law ${ }^{71}$-that owners facilitate lawful acts in relation to TPM-protected works. Reichman and his co-authors suggest a "reverse notice-and-takedown" regime which operates on a similar premise: "users would be able to give copyright owners notice of their desire to make public interest uses of technically protected copyrighted works, and right holders would have the responsibility to take down the TPMs or otherwise enable these lawful uses" (Reichman et al., 2007, p. 985). ${ }^{72}$ Such a system must make provision for situations where owners do not take adequate steps to make the work available within a reasonable time, or where users have privacy or other concerns that make it unreasonable to expect them to request assistance from the copyright owner. There are various options at this stage, none of which is, admittedly, ideal. It may not be sufficient to permit a would-be user to initiate a legal action before the court, or to instigate formal arbitration or mediation proceedings, particularly if relief is limited to the specific party seeking it. A less onerous or costly route should be found if the goal is to prevent TPMs from unduly inhibiting lawful uses.

An appropriate mechanism for the enforcement of exceptions may require the identification of an intermediary body or bodies to facilitate fair dealings and permitted acts. One approach may be simply to require unencrypted copies of works to be lodged at certain public institutions (libraries, educational institutions, etc.) either on request or by legal mandate. Under such a scheme, notice requirements on protected copies could indicate the sources of TPM-free versions. ${ }^{73}$ Alternatively, an intermediary could be entrusted with providing circumvention services or devices on request, which would yield traceable copies of protected works. In one version of this model, the assigned body would perform a gatekeeper role with the responsibility of making initial determinations as to the merit of applicants' claims; another version would reduce this role to a merely ministerial one whereby circumvention services and devices would be automatically distributed in response to recorded requests (Besek, 2004, pp. 494-5). In this vein, Dan Burk and Julie Cohen have proposed a "key escrow" system in which an 
independent third party institution would be responsible for providing digital keys to beneficiaries of copyright limitations (Burk and Cohen, 2001). In order to best replicate traditional fair use practices, Burk and Cohen envisage a simple online application procedure, with keys being provided on request without assessment of the lawfulness of dealings, and with any records being subject to strict privacy conditions. A middle road could see the intermediary charged with responsibility for obtaining declarations of lawful use from applicants, and ensuring only that such declarations meet applicable statutory requirements. The declaration could be required to contain, for example, identification, a statement of qualified status, and the specific exemptions of which the party intends to take advantage (Besek, 2004 pp. 495-6). ${ }^{74}$

The development of an appropriate lawful use infrastructure is a complicated proposition fraught with problems of both practicality and principle. Difficult questions would surround the identification of appropriate intermediaries or "qualified" persons or institutions to take on the "gatekeeper" function. To encumber existing public institutions such as libraries, archives or educational establishments with this additional responsibility may not be appropriate or viable, particularly if the intermediary function is to demand some degree of legal and/or technical expertise. It may require the creation of a new administrative agency, such as that recently constituted in France, or the assignation of new powers and responsibilities to an existing body such as the Copyright Board, for example. In any case, the initial and ongoing operational costs could be substantial. There is also the very real risk that such infrastructural costs could prove unwarranted, either because the system fails to adequately stem the flow of unauthorized copies, or because changes in market practices quickly render it redundant.

From a principled perspective, the identification of too few or the wrong intermediaries could result in a "centralization of copyright limitations where only a few actors determine who benefits from such limitations, and for what purpose" (Bechtold, 2004, pp. 376). In addition, a system that requires users to identify themselves and their intended activities in order to benefit from exceptions inevitably raises significant privacy concerns that would have to be overcome (Burk and Cohen, 2001, pp. 63-5). Perhaps most fundamentally, however, it is all but impossible to conceive of a lawful use mechanism that does not have a chilling effect on fair dealing practices by increasing user transaction costs and inhibiting spontaneous uses. Traditionally, users have been able to "use now, litigate later"; TPM protection offers preemptive control to owners, forcing would-be users to "stop now, establish the right-to-use later." The prior restraints imposed by technical barriers undercut the agency and autonomy of users (Gillepsie, 2007, pp. 255-61), ensuring that even the best examples of anti-circumvention legislation fail to give effect to the subtleties and fluidities of creative play.

In light of these concerns, any new anti-circumvention regime must incorporate tools to permit continuous monitoring of its application and effects on user practices. Procedures should be put in place to ensure the systematic identification and assessment of the impact of TPM protection (Gasser, 2006, pp. 104-5). These should include, in addition to periodic and frequent administrative review, a simple, accessible and affordable mechanism for members of the public to raise concerns about restrictions on lawful uses. Particularly if the anti-circumvention regime operates with a system of enumerated narrow exemptions, it will be crucial to offer an 
efficient and impartial process to allow the prompt regulation of new exceptions in response to public concerns.

\section{Digital Locks and the Limits of Prescriptive Parallelism}

Whatever legal framework emerges from the digital copyright reform process, however, the problems and implications of TPMs are likely to be more far-reaching and intractable that these proposed legislative "solutions" may intimate. After all, simply to accept the logic of additional legal protection for TPMs is to accept that the use of TPMs should be supported (in the sense of being both encouraged and strengthened), and so to concede a role for digital locks in our copyright system. And so it would be remiss to conclude without highlighting a few "bigger picture" considerations that underscore the risks and potential impact of such a concession.

First, we should be aware of the risk that the legal protection of TPMs will shore up the rights of existing owners and generally maintain the status quo for many of the powerful industry actors presently pushing for legislative reform. The creation of anti-circumvention rights responds to the perceived threats posed by networked technologies, with stronger entitlements intended to guarantee a foothold for existing stakeholders in emergent markets (Ganley, year, p. 55). Anti-circumvention laws may therefore have an entrenchment effect, with the possible consequence of prematurely foreclosing the emergence of new industry actors and the evolution of new models or avenues of dissemination. ${ }^{75}$ While it is self-evident that existing industry stakeholders would hope to achieve such entrenchment, it is by no means clear that policy-makers should share this goal. To the extent that policy-makers adopt the defensive posture of rightholders and established industry actors, they risk circumscribing the creative, democratic and participatory opportunities that these technologies present for society at large.

And if TPM protection appears necessary to strengthen the control offered by existing copyright law, we should consider the further risk that the creation of new rights will only obfuscate the more fundamental failings of copyright in our networked society. Proponents of anti-circumvention legislation frequently point to massive increase and pervasiveness of copyright infringing activities amongst members of the general public as support for TPM protection. We must, however, take care not to bandage over wounds that are in need of proper attention. The pervasiveness of end-user infringements points to a growing disconnect between social norms (old and emerging) and legal norms (traditional and proposed). This increasingly chasmic divide suggests an even greater cause for concern: namely, the changing role and relevance of copyright law in everyday cultural exchange and creative play, and the way in which this challenges the normative foundations of the copyright system. Strengthening existing laws and enacting new ones is potentially a quick but fleeting fix to a larger socionormative quandary. Where established and emerging user practices challenge the coherence of social and legal norms, the latter become increasingly costly and difficult to enforce. The imposition of legal norms that are not sufficiently internalized by many or most citizens could threaten the perceived legitimacy of the copyright system, and compromise the rule of law more generally (Gervais, 2005, pp. 48-53). ${ }^{76}$ 
We should also appreciate the extent to which TPMs and their protection threaten to change the established rules of the game. Leaks, limits and the tough practicalities of enforcement have always been an important part of the architecture of the copyright system and the way that it achieved its so-called balance. To the extent that TPMs are lauded as practical means by which to ameliorate these problems, we should ask whether they are problems that need solving. If copyright were to operate in practice in perfect harmony with copyright law as it exists on the book, the system would be far from perfect: because copyright as a system works better when it "leaks," perfect control is a fallacious ideal. ${ }^{77}$ Similarly, the ambiguity of legal doctrines such as fair dealing is not a flaw but a vital feature of the system. The boundaries of fair dealing are fluid, its application context-specific, and its scope subject to interpretation: as a result, many uses will be routinely undertaken and remain un-litigated because they belong in the penumbra of doubt that makes them possibly fair-and possibly infringing (see Gillepsie, 2007, p. 59). Broad TPM protections will permit the indeterminacy of legal doctrine-which has been so central to the preservation of breathing space for fair dealing practices - to be supplanted by the determinacy of technology.

Although better control does not necessarily make a better system, the quest for perfect control finds legitimation in the proprietary rhetoric of intellectual property. Thus, for example, protected content is cast as private property, and the circumvention of TPMs is equated with breaking and entering: it is no more permissible, according to some proponents of anticircumvention law, to circumvent a TPM to exercise a permitted act, than it is to break into a car to make fair use of a manuscript left inside. With every such analogy, a counter-analogy can be found: it is no more permissible, one might say, to employ TPMs to prohibit access to lawful users than it is to erect fences around public land. The inappropriate extension and use of such metaphors can obscure questionable assumptions and unsubstantiated claims, as can reliance on purported parallels without adequate distinctions being drawn. ${ }^{78}$ And so, finally, there is the risk that added protection for TPMs will further entrench the misleading proprietary rhetoric that has pervaded the TPM debate, and lend weight to the perception of intellectual property as absolute dominion (Ganley, 2006, p. 56). It is crucial that we identify and challenge the expansion (and frequent misapplication) of property rhetoric that has and will accompany new claims to right, and avoid the muddied moralistic reasoning that such rhetoric is intended to evoke. The validity of claims and their policy rationales should be assessed on their own terms and with the public policy goals of the copyright system clearly in view.

\section{CONCLUSION}

Canadian policy makers continue to contemplate the appropriate design for a new layer of rights that will afford greater protection to owners in the digital environment. In my opinion, the clearest route towards retaining roughly the same balance between copyright owners and users in this new environment would be, first, to refrain from creating anti-circumvention rights, and second, to establish an effective system to facilitate lawful acts in relation to TPMprotected works. The latter would require the enactment of a positive obligation for 
rightholders to provide the necessary means for users to take advantage of recognized exceptions, and would benefit from the creation of an intermediary body to receive user requests and distribute circumvention devices or services or TPM-free copies. Under such a model, owners would continue to enjoy the advantages of technical measures to reinforce their practical control over legally protected works, while users would be both practically able and legally entitled to make lawful uses of these works.

If anti-circumvention rights are to be created, however, I have suggested that it may be possible to substantially meet the principled demands of prescriptive parallelism by carefully constructing these rights around the existing corner-stones of Canadian copyright policy. These rights should, for example, be made contingent on certain formalities or guarantees; directly tied to copyright infringing activities so that circumvention for non-infringing purposes remains lawful; restricted to circumvention activities so that circumvention technologies are not per se restricted; made subject to broad and explicit fair and lawful use exceptions; and conditional on accessible mechanisms to ensure the practical availability of these exceptions. To the extent that such proposals sound unwieldy, this should be heard as a cautionary note not against the requirements and limits described, but rather against any legislative intervention to reinforce TPMs through the copyright system.

While an ideal solution to the challenge of preserving the copyright balance remains elusive, canvassing these possibilities reveals one thing with certainty: the anti-circumvention provisions of Bill C-61 were far from an ideal solution. Canada's copyright balance of rights and exceptions will be preserved in the digital environment only by resisting external pressures, by identifying and learning from best and worst practices in other jurisdictions, and most importantly, by taking seriously the centrality of fair dealing and the public domain within copyright law.

Whatever broad principles and policies may ultimately inform the shape of anti-circumvention regulations, it should be borne in mind that, fundamentally, TPMs confer primacy to private ordering. While proponents of anti-circumvention laws have "taken cover under the umbrella of copyright rhetoric" (Gillepsie, 2007, p. 274), the legal protection of TPMs will privilege private efforts to control access, distribution, use and consumption of digital content, marginalizing the public interest and social welfare considerations that have informed the development of the copyright system and its delicate balance. The proliferation of TPMs is altering the way in which we experience and engage with cultural resources in our networked society-but a new layer of legal entitlement attached to TPMs would alter the role that copyright plays in regulating our cultural life.

From a socio-cultural perspective, the larger threat so readily obscured by practical pleas and political arguments is that, through a combination of technical pragmatism and misguided policy, we fail to realize the full benefits and potential (fulfill the promise, if you will) of the digital era. In Robertson v Thomson Corp. ${ }^{79}$ Justice Abella considered copyright's capacity to "keep pace with technological developments to foster intellectual, artistic and cultural creativity," and stated that, when considering how to regulate the Internet and new 
technologies, "the public benefits of this digital universe should be kept prominently in view." 80 Citing Geist (2006, p. 9), the minority judgment continues: "The Internet and new technologies have unleashed a remarkable array of new creativity, empowering millions of individuals to do more than just consume our culture, instead enabling them to actively and meaningfully participate in it." 81 Such statements seem to hold promise of a copyright system that respects and reflects the transformative possibilities of new technologies rather than resisting and constraining the emerging cultural practices that these technologies permit. ${ }^{82}$ As we consider reforming our copyright laws in response to the digital shift, we should be committed to realizing this promise.

\section{Notes}

The author wishes to thank the organizers of the University of Toronto 2009 Copyright Symposium (part of the Centre for Innovation Law \& Policy's Microsoft Information Society Project). In particular, thanks go to Abraham Drassinower and Andrea Slane for the opportunity to participate, and to Richard Owens for his challenging counter-arguments. A debt of gratitude is also owed to Tamsin Thomas for her research and editorial assistance.

1 This is an important conceptual distinction, if not always a practical one. As Kerr and his co-authors (2002-2003, p. 13) explain, in reality, TPMs often display use control and access control characteristics, making the distinction difficult to maintain, and complicating any effort to legislate activities in relation to one kind of TPM and not the other.

2 Notably, the Canadian copyright balance, as articulated by the Supreme Court of Canada in Théberge $v$ Galerie d'Art du Petit Champlain Inc. 2002 SCC 34 (Théberge), preserves, as an equal and distinct objective, providing a just reward for authors. I have argued elsewhere that the provision of individual reward can and should be subsumed within the general public goal of encouraging the creation and dissemination of intellectual works (see Craig, 2002), but such a conclusion is not necessary to support the argument advanced here.

3 The teleological argument that underlies the demands for stronger legal rights is neatly articulated by James Boyle: "[T]he strength of intellectual property rights must vary inversely with the cost of copying," from which it appears to follow that "as copying costs approach zero, intellectual property rights must approach perfect control" (2008, pp. 60-1).

4 The Working Group reasoned:

[L] egal protection alone will not be adequate to provide incentive to authors to create and to disseminate works to the public. Similarly, technological protection likely will not be effective unless the law also provides some protection for the technological processes and systems used to prevent or restrict unauthorized uses of copyrighted works. The Working Group finds that prohibition of devices, products, components and services that defeat technological methods of preventing unauthorized use is in the public interest and furthers the Constitutional purpose of copyright laws (White Paper, 1995, p. 230, emphasis added).

5 WIPO treaties (1996) [online]. Available at $<$ http://www.wipo.int/treaties/en/ip/wct/trtdocs_wo033.html $>$ and $<\mathrm{http}$ ://www.wipo.int/treaties/en/ip/wppt/trtdocs_wo034.html > [Accessed on October 2009].

6 A striking example is the elimination of a draft article that would have recognized a right of copyright owners to control temporary reproductions of their work in a computer's RAM.

7 For a detailed account of the US agenda at WIPO and its impact on the resulting treaties, see Samuelson (1997). With regard to the regulation of circumvention technologies specifically, see Litman (2001, pp. 129-33).

8 Article 18 of the WPPT, supra note 5, reads:

Contracting Parties shall provide adequate legal protection and effective legal remedies against the circumvention of effective technological measures that are used by performers or producers 
of phonograms in connection with the exercise of their rights under this Treaty and that restrict acts, in respect of their performances or phonograms, which are not authorized by the performers or the producers of phonograms concerned or permitted by law.

9 Samuelson argues that US law would have satisfied Article 11 obligations without the enactment of the Digital Millenium Copyright Act.

10 This interpretation of the text of Article 11 is not without its critics. As Kerr and his co-authors (2002-2003) acknowledge, the article could be read to mean that protected TPMs include those which restrict acts in relation to works that are not authorized by authors (i.e. as well as those restricting acts that are not permitted by law) (p. 36).

11 Howard Knopf (2008) Canada, WIPO, and certain “obligations” [online]. Available at $<$ http://excesscopyright.blogspot.com/2008/02/canada-wipo-and-certian-obligations.html $>$ [Accessed on October 2009]. Knopf cites in support J. Craig Barker:

The effect of signature is not, as one might expect, to bind a state to the terms of a treaty.... A state that has signed, but not yet ratified, a treaty is bound not to do anything contrary to the objects and purposes of that treaty prior to ratification or withdrawal of signature. However, a state is not bound to follow the terms of a treaty in their entirety until ratification (2002).

12 The text continues: "the ratification process would only be considered after further work has been completed." See Government of Canada (2008a).

13 Not everyone is a critic of such a development, however. See, e.g. Bell (1998).

14 See Ginsburg (2001):

The 'copyright balance' is hardly immutable... It is far from apparent why the 'balance' in force from the advent of [mass market copying] devices should be more normative and less contingent that the prior 'balance,' or than the now emerging balance (p. 5).Notably, Ginsburg does not present the access-right as a wholly new creation of the digital era, but rather suggests that it was arguably "implicit in the reproduction and distribution rights under copyright in the days before mass copying devices. The copyright owner controlled access by choosing how to make the work available." See also Olswang (1995); Heide (2001).

15 For further discussion, see infra.

162004 SCC 13, [2004] 1 S.C.R. 339, (CCH, cited to S.C.R.).

17 I should note that fair dealing is best understood as part of the public domain, and has been recognized by the Supreme Court of Canada as such. In Théberge, supra note 2, Justice Binnie opined that the exceptions to copyright infringement enumerated in the Copyright Act "seek to protect the public domain in traditional ways such as fair dealing for the purpose of criticism or review and to add new protections to reflect new technology, such as limited computer program reproduction and 'ephemeral recordings' in connection with live performances" (paragraph 32).

18 Copyright Act, R.S.C. 1985, c. C-42 [online]. Available at $<$ http://laws.justice.gc.ca/en/C-42/> [Accessed on October 2009].

19 There are therefore three hurdles to be met by a defendant who claims to have dealt fairly with a work: first, the purpose must be one of those listed in the Act; second, the dealing must be fair; and finally, sufficient acknowledgement must have been given where statutorily required.

20 "[T] and dissemination of works of the arts and intellect and obtaining a just reward for the creator" (CCH, supra note 16, paragraph 23).

21 The Court allowed the defendant Library to claim a "research" purpose in the provision of copying services to its patrons. In recognition of the public purposes of the Copyright Act, the Court opined that a more inclusive approach to applying the fair dealing defence was necessary.

22 In order to be fair, a dealing must be for the purpose of research, private study, news reporting, criticism or review; and it must be "fair", which is "a question of fact and depends on the facts of each case" ( $\mathrm{CCH}$, supra note 16, paragraph 52). Although there is no "set test," determinations of fairness involve consideration of several factors, which may include (1) the purpose of the dealing; (2) the character of the dealing; (3) the amount of the dealing; (4) alternatives to the dealing; (5) the nature of the work; and (6) the effect of the dealing on the work (ibid., paragraph 53).

23 Digital Millennium Copyright Act, Pub.L. No. 105-304, Title I, 112 Sta. 2860 (1998), codified at 17 U.S.C. §1201(a)-(b) (1999) (DMCA) [online]. Available at 
$<$ http://www.copyright.gov/legislation/dmca.pdf $>$ [Accessed on October 2009]. Litman (2001) comments:

Copyright owners who want to ensure that they control — and can charge money for - any appearance of their works in any computer anywhere... were able to persuade Congress to pass the Digital Millennium Copyright Act, which encourages the use of technological protections to facilitate a pay-per-view, pay-per-use system...” (p. 27).

24 Ultimately, in recognition of all that is currently unknown and unforeseeable, Kerr and colleagues' report advised against the implementation of any new legal measures in Canada to protect TPMs for the time being.

25 Kerr and co-authors (2002-2003) note that that legal protection for TPMs is inherently contrary to the principle of media or technology neutrality.

26 See Apple Inc. (2009) Changes Coming to the iTunes Store [online]. Available at $<$ http://www.apple.com/pr/library/2009/01/06itunes.html > [Accessed on October 2009].

27 In its Copyright Reform "Backgrounder," the Government of Canada (2008b) states:

The Internet has threatened the ability of rights holders to prevent the unauthorized use of works and other protected subject matter. People around the world have taken advantage of the Internet to access content that is available in user-friendly forms. This access is often made through new legitimate services and platforms, and also via free alternatives, both legitimate and illegitimate, to the traditional channels of distribution of copyright material.

See also Barry B. Sookman (2005): “TPM's are essential to limiting the ease of carrying out copyright infringement in the digital environment. Without adequate legal protection and effective legal remedies against the circumvention of TPMs, [the] goals [of Canadian copyright policy] will be undermined" (p. 26).

28 See, e.g., Pamela Samuelson (1999):

Clinton Administration officials, bowing to the wishes of Hollywood and its allies, opted...to support an unpredictable, overborad, and maximalist set of anti-circumvention regulations.... It was, in short, not the needs of the digital economy that drove adoption of the anti-circumvention provisions in the DMCA. Rather, what drove the debate was high rhetoric, exaggerated claims, and power politics from representatives of certain established but frightened copyright industries (p. 533).

29 While 1201(a)(2) prohibits trafficking in devices that circumvent access controls, 1201(b) prohibits trafficking in circumvention devices designed or produced to circumvent TPMs that protect the exclusive rights of copyright holders in the Copyright Act (e.g. those measures that copyright owners employ to prevent unauthorized reproduction of the work).

30 Samuelson (1999) argues that "the enumerated exceptions in the act-of-circumvention ban are unduly narrow and inconsistent with framework principles" (pp. 537-46).

31 The list also includes: circumvention to achieve interoperability of computer programs (§1201(f)); circumvention to prevent minors from accessing material on the Internet (§1201(h)); circumvention when either the technical measure or the work collect of disseminate personally identifying information about the user's online activities ( $(1201(\mathrm{i})$ ); circumvention to test the security of a computer, computer system, or network $(\S 1201(\mathrm{j}))$. Note that only three of these exceptions apply to one or both of the anti-device rules: the exception for reverse engineering may, subject to limitations, permit a person to develop and make available the means of circumventing both accessand rights-control TPMs to achieve interoperability; encryption research and security testing exceptions are, subject to limitations, available for the development and distribution of devices necessary to circumvent access-control measures only.

32 For example, an exemption exists for "[c]omputer programs in the form of firmware that enable wireless telephone handsets to connect to a wireless telephone communication network, when circumvention is accomplished for the sole purpose of lawfully connecting to a wireless telephone communication network." All six exemptions can be found online. Available at $<$ http://www.copyright.gov/1201/2006/index.html> [Accessed on November 2009]. The fourth anti-circumvention rulemaking proceeding (2009) is in progress at the time of this writing.

33 Herman and Gandy (2006) provide a fascinating account of the emergence and implementation of this procedure, criticizing the scheme for "taking the responsibility for ensuring fair use away from 
the courts and giving it to an obscure, relatively toothless rulemaking process," and "leaving wider fair use concerns without a venue" (p. 188).

34 For a number of illustrative examples of restrictions imposed by the DMCA, see Kerr et al. (20022003, pp. 69-74). A full list of DMCA cases that have presented fair use, free speech and privacy concerns can be found online. Available at $<$ http://www.eff.org/issues/dmca $>$ [Accessed on November 2009].

35111 F. Supp. 2d 294 (SDNY 2000).

36 Sub. nom. Universal City Studios, Inc. v Eric Corley, 273 F.3d 429 (2nd Cir. 2001) (Corley). 37 Ibid., p. 429.

3871 Fed. Reg. 68472, 68473 (November 27, 2006).

39 Directive 2001/29/EC on the Harmonisation of Certain Aspects of Copyright and Related Rights in the Information Society, art.6 2001 O.J. (L 167) 10 (Copyright Directive) [online]. Available at < http://eur-lex.europa.eu/LexUriServ/LexUriServ.do?uri=OJ:L:2001:167:0010:0019:EN:PDF > [Accessed on October 2009]. In accordance with Article 6(3), the protection encompasses the act of circumvention and trafficking in devices and services both in relation to copyright control measures and access control measures.

40 Reichman et al. identify article 6(4) as "one dimension of parallelism in the EU Directive." Riechman cites Hugenholtz (2000): "[Article 6(4)] is presumably intended to reconcile the interests of right owners employing technical protection measures with the interests of users wishing to benefit from copyright limitations" (p. 501)

41 "'Fair use by mandate' describes circumstances in which rightholders are directed to enable noninfringing uses but not necessarily given specific instructions as to how that should be done" (Besek, 2004, p. 492).

42 See Dusollier (2003): "Would any measure, even a minimal one, free the State from its legislative duty to safeguard the public interest? If it did, too much unrestrained power would go to authors and other rights holder of copyrighted works" (p. 53).

43 Article 6(4), Copyright Directive, supra note 39.

44 The intended scope of this carve-out is not entirely clear. For example, does an online music store qualify as an interactive on-demand service? See Gasser and Girsberger (2004, p. 25) and Brown and Bohm (2003) (describing this as "a dramatic reduction of copyright users' rights that needs urgent revision in the review of the Directive" [p. 21]); and Dusollier (2003, p. 54).

45 Included are exceptions concerning: specific reproductive acts by libraries, educational establishments, museums or archives without commercial advantage; certain acts in respect of ephemeral recordings; reproductions of broadcasts by social institutions for non-commercial purposes; certain illustrative uses in teaching or scientific research; certain uses for the benefit of persons with a disability; and certain uses for the purpose of public security. On the apparently arbitrary nature of this selection, see: Institute for Information Law, 2007, p. 110; cited in Reichman et al., 2007, at note 312; see also Dusollier, 2003, p. 53.

46 See also Reichman et al. (2007): "[T]he failure to mandate the adoption of a wide range of exceptions undermines the effectiveness of Article 6(4) in achieving its general goal of prescriptive parallelism" (p. 1043)

47 Compare to Dusollier (2004): "Behind a balanced, publicly oriented exterior...lies a privateorderings model in which author interests are privileged and preserved" (p. 55). See also Weise (2002):

[T] he Directive permits a scenario where there is virtually nothing left of the traditional copyright balance: a world where fair use rights are dead since most circumvention acts and all circumvention devices are prohibited; a world where copyright law would be replaced by technological monopolies and electronic contracts (p. 151).

48 Section 374(3) of the Irish Copyright and Related Rights Act states that beneficiaries of exceptions "may apply to the High Court for an order requiring a person to do or to refrain from doing anything the doing or refraining from doing of which is necessary to ensure compliance with the provisions of this section" (cited in Gasser, 2004, p. 79). The Act is available online at $<$ http://www.irishstatutebook.ie/2000/en/act/pub/0028/index.html > [Accessed on November 2009]. Section $95 b(2)$ of the German Law for the Regulation of Copyright in the Information Society similarly provides right to claim from rightholders the necessary means to benefit from exceptions. 
Available at $<$ http://www.urheberrecht.org/topic/Info-RiLi/ent/Bundesrat_Drucksache_271_03.pdf $>$ [Accessed on November 2009]. Section 71 quinquies(2) of Luxemburg's revised Law on Copyright, Neighbouring Rights and Databases entitles beneficiaries to take injunction proceedings. Available at $<$ http://www.wipo.int/clea/en/text pdf.jsp?lang=FR\&id=2933 $>$ [Accessed on November 2009].

49 Added to the Copyright, Designs and Patents Act 1988 by the Copyright and Related Rights Regulations 2003, 2003, S.I. 2003/2498 (U.K.). For further information see Shah (2004).

50 Created by the Loi sur le Droit d'Auteur et les Droits Voisins dans la Société de l'Information (DADVSI). The body consists of six members appointed for a six year term after designation by their respective bodies: see Decree of 4 April 2008 concerning the Regulatory Authority on technical protective devices created by Article L. 331-17 of the Intellectual Property Code, published in the Journal Officiel of 5 April 2008; see also Berbinau (2007) and Blocman (2007).

51 Pursuant to subsection $226 \mathrm{E}(2)(\mathrm{b})$, the user may engage a qualified person to exercise the permitted act on his or her behalf only if the copyright owner or the exclusive licensee has refused the user's request for assistance or has failed to respond to it within a reasonable time.

52 In its original enactment of anti-circumvention laws, Australia also included means by which lawful users could obtain circumvention devices or services from "qualified persons" to enable or facilitate permitted uses: Copyright Amendment (Digital Agenda) Act 2000 No. 110, 2000 (Cth), section $116 \mathrm{~A}(3)$. However, following the coming into force of the Australia-United States Free Trade Agreement 2005 [AUSFTA], available at <www.dfat.gov.au/trade/negotiations/us_fta/final-text/> [Accessed on November 2009], Australia has enacted revised anti-circumvention provisions that more closely align with the approach taken in the DMCA. Revised Copyright Act 1968 available at $<$ http://www.austlii.edu.au/au/legis/cth/consol_act/ca1968133.txt> [Accessed on November 2009]. See also, Weatherall (2004-05).

53 Technological measures were defined in the bill as "any technology, device or component that, in the ordinary course of its operation, restricts the doing... of any act that is mentioned in section 3,15 , or 18 or that could constitute an infringement of any applicable moral rights." In other words, a protected TPM is one that ordinarily restricts infringing activities. Bill C-60, An Act to Amend the Copyright Act, section 1(2) [online]. Available at $<$ http://www2.parl.gc.ca/HousePublications/Publication.aspx?pub=bill\&doc=c$60 \&$ parl $=38 \&$ ses $=1 \&$ language $=\mathrm{E}>$ [Accessed on November 2009].

54 Subsection 80(1) provides that, subject to certain limitations, it does not infringe copyright to make an audio-recording of a musical work for private use. As such, s. 32.02 of the bill did extend circumvention liability beyond existing copyright liability with regard to private copies of sound recordings that would have benefited from ss. 80(1) but for the use of TPMs to protect the material embodiment of the musical work.

55 Geist asks whether, for example, distributing software that is frequently used for infringing purposes might be caught (i.e. knowledge that the service is likely to be used to infringe copyright), or whether the section would require direct knowledge of a specific infringing purpose (Geist, 2005, p. 242).

56 See also Kerr (2005): "[T]he proposed anti-circumvention laws protect these [DRM] technologies without protecting people from excessive or illegitimate uses of them" (p. 210).

57 "Technological measures" were defined to include "any effective" technology that "in the ordinary course of its operation" either "controls access" to a work or "restricts the doing" of any infringing acts. Bill C-61 (An Act to Amend the Copyright Act), section 41 [online]. Available at $<$ http://www2.parl.gc.ca/HousePublications/Publication. aspx? DocId=3570473\&Mode=1\&Language $=\mathrm{E}>[$ Accessed on November 2009].

58 Pursuant to section 41.1(1)(c), no person shall "manufacture, import, provide—including by selling or renting - offer for sale or rental or distribute" circumvention technologies, devices or components.

59 Under section 41.1(1)(c)(i), the prohibition applies if "the technology, device or component is designed or produced primarily for the purposes of circumventing a technological measure."

60 Under section 41.1(1)(c)(ii), the prohibition applies if "the uses or purposes of the technology, device or component are not commercially significant other than when it is used for the purposes of circumventing a techno- logical measure." 
61 Section 41.1(1)(c)(iii): the prohibition applies if "the person markets the technology, device or component as being for the purposes of circumventing a technological measure or acts in concert with another person in order to market the technology, device or component as being for those purposes." The same factors are applied to determine whether services are caught by the prohibition in section 41.1(1)(b).

62 Section 41.2(2)(b) states: "The regulations may prescribe the manner in which, and the time within which, access is to be provided, as well as any conditions that the owner of the copyright is to comply with."

63 As Geist (2008) observed on his blogsite, "Bill C-61 establishes the criteria for the introduction of new circumvention rights but fails to implement an administrative structure to conduct the reviews."

64 Section 29.21 creates an exception for "an individual to reproduce a work or other subject-matter that is a photograph or is contained in a book, newspaper, periodical or videocassette, or any substantial part of such a work or other subject-matter, onto another medium or device" but subject to certain conditions, which include "(c) the individual, in order to make the reproduction, did not circumvent a technological measure or cause one to be circumvented." This exception is an illustrative example of the narrow precision with which the bill sought to carve out permitted acts. See also sections 29.22(1)(c) (which similarly limits the exception for an individual who reproduces "onto a medium or device a musical work embodied in a sound recording), and section 29.23(1)(b) (which similarly limits the exception created for the fixing of communication signals to record a program for the purpose of listening to or watching it later).

65 The Digital Media Consumers' Rights Act bill was introduced to the US House of Representatives in January 2003 (H.R. 107) and reintroduced in March 2005 (H.R. 1201). The "Freedom and Innovation Revitalizing U.S. Entrepreneurship" (or FAIR USE) Act was introduced in February 2007 (H.R. 1201).

66 See Ganley (2004, p. 55) discussing the potential advantages of conditioning anti-circumvention provisions on a set of positive steps taken by rightholders.

67 New Zealand's Copyright (New Technologies) Amendment Act 2008, Section 226, includes in its definition of TPM the following clarification:

(b) for the avoidance of doubt, [TPM] does not include a process, treatment, mechanism, device, or system to the extent that, in the normal course of operation, it only controls any access to a work for non-infringing purposes (for example, it does not include a process, treatment, mechanism, device, or system to the extent that it controls geographic market segmentation by preventing the playback in New Zealand of a non-infringing copy of a work).

68 The Copyright Act makes it unlawful to authorize an infringing act: ss. 3, 27(1). The Supreme Court explained in Society of Composers, Authors and Music Publishers of Canada v Canadian Association of Internet Providers, 2004 SCC 45 at paragraph 127:

The knowledge that someone might be using neutral technology to violate copyright (as with the photocopier in the $\mathrm{CCH}$ case) is not necessarily sufficient to constitute authorization, which requires a demonstration that the defendant did '(g)ive approval to; sanction, permit; favour, encourage' the infringing conduct (Citing $\mathrm{CCH}$, supra note 16, paragraph 38).

69 For further discussion, see infra.

70 Compare to Kerr et al, (2002-2003) where they propose a possible "access-to-works right" that could impose upon copyright owners a "positive obligation to to provide access-to-a-work when persons or institutions fall within an exception or limitation set out in the Copyright Act" (p. 78).

71 Section 95b(1) of the German Copyright Act (UrhG), added by the Law for the Regulation of Copyright in the Information Society 2003, requires rights-holders to provide necessary means for users to benefit from recognized exemptions.

72 For a detailed description of how such a system may be effectively implemented through judicial or administrative measures, see Reichman et al. (2007, pp. 1045-60).

73 If lawful users are not to be unduly disadvantaged, these versions should be digital and not merely "analogue" or hard copies. However, such a system is likely to raise objections on the basis that the availability of TPM-free digital copies could quickly render the use of technical protections redundant. Perhaps a combination of record keeping and digital marking (together with strict privacy controls) could minimize such objections. 
74 Compare to Australia's Copyright Amendment (Digital Agenda) Act 2000, section 116A(3), discussed supra note 52, under which the supplier of circumvention devices and services performed this limited intermediary role. The declaration required could be similar in type to the declaration of lawful purpose obtained by the Great Library from its patrons under the access policy approved by the Supreme Court in $\mathrm{CCH}$. See $\mathrm{CCH}$, supra note 16 at paragraph 61.

75 But compare with Sookman (2005) arguing that protection for TPMs will stimulate investment in innovative business models, support the development of e-commerce, and thereby serve the public interest.

76 Gervais (2005) warns: "If policy makers insist on making illegal socially-acceptable conduct, technology will adapt to the legal environment either by circumventing the legal norm or by making enforcement either impossible or too costly"(p. 52).

77 Much of what strikes the layperson or law student as counter-intuitive or even nonsensical about copyright law is also largely irrelevant in light of market realities and basic practicalities. Many common user practices may not be legal, but are overlooked by owners either because they are not readily identified, they are recognized as potentially beneficial, or the financial or public relation costs of pursuing them are not worth assuming (see Gillespie, 2007, pp. 59-60).

78 For an interesting discussion of metaphor in the context of the TPM debate, see Herman (2008).

792006 SCC 43, 2 S.C.R. 363, paragraph 79 (Robertson).

$80 \mathrm{Ibid}$.

$81 \mathrm{Ibid}$.

82 Tempering this optimism somewhat, it should be noted that these statements were made by Justice Abella in the context of a minority judgment. The majority appeared less concerned with ensuring that copyright not interfere with the advantages offered by new technologies: "Media neutrality is not a licence to override the rights of authors - it exists to protect the rights of authors and others as technology evolves" (Ibid., para. 49).

\section{References}

Akester, P. (2009) 'Technological Accommodation of Conflicts between Freedom of Expression and DRM: The First Empirical Assessment' [online]. Available at < http://www.law.cam.ac.uk/faculty-resources/download/technologicalaccommodation-of-conflicts-between-freedom-of-expression-and-drm-the-firstempirical-assessment/6286/pdf > [Accessed on October 2009].

Barker, J.C. (2002) 'Mechanisms to Create and Support Treaties, Conventions and other Responses' UNESCO Encyclopaedia of Life-Support Systems, EoLss Publishers, Paris [online]. Available at <http://www.eolss.net/EolssSampleChapters/C14/E1-4401/E1-44-01-TXT-02.aspx $>$ [Accessed on October 2009].

Bechtold, S. (2004) 'Digital Rights Management in the United States and Europe', American Journal of Comparative Law, 52, 323-382.

Bell, T.W. (1998) 'Fair Use vs. Fared Use: The Impact of Automated Rights Management on Copyright's Fair Use Doctrine', North Carolina Law Review, 76, 557-620.

Berbinau, J. (2007) 'Copyright in Cyberspace: Towards a Workable Balance: Setting up a

Regulatory Authority', [online]. Available at

$<$ http://www.armt.fr/IMG/doc/IPO2007.doc > [Accessed on October 2009].

Besek, J.M. (2004) 'Anti-Circumvention Laws and Copyright: A Report from the Kernochan

Center for Law, Media and the Arts', Columbia Journal of Law \& the Arts, 27, 385-517.

Blocman, A. (2007) 'Setting up of the Regulatory Authority on Technical Protection

Measures', IRIS 2007-5:9/13 [online]. Available at 
$<$ http://merlin.obs.coe.int/iris/2007/5/article13.en.html $>$ [Accessed on October 2009].

Boyle, J. (2008) The Public Domain: Enclosing the Commons of the Mind. Yale University Press, New Haven, CT.

Brown, I. and Bohm, N. (2003) Implementing the EU Copyright Directive. Foundation for Information Policy Research [online]. Available at $<$ http://www.fipr.org/copyright/guide/eucd-guide.pdf> [Accessed on October 2009].

Burk, D.L. and Cohen, J.E. (2001) 'Fair Use Infrastructure for Rights Management Systems', Harvard Journal of Law and Technology, 15, 41-83.

Commission of the European Communities (2007) Report to the Council, the European Parliament and the Economic and Social Committee on the application of Directive 2001/29/EC on the harmonisation of certain aspects of copyright and related rights in the information society, Commission Staff Working Document, SEC(2007) 1556, 30/11/2007 [online]. Available at <http://www.ipex.eu/ipex/webdav/site/myjahiasite/groups/CentralSupport/public/2 007/SEC 2007 1556/COM SEC(2007)1556 EN.doc> [Accessed on October 2009].

Craig, C. (2002) 'Locke, Labour and Limiting the Author's Right: A Warning Against a Lockean Approach to Copyright Law', Queen's Law Journal, 28, 1-60.

Craig, C. (2005) 'The Changing Face of Fair Dealing in Canadian Copyright Law: A Proposal for Legislative Reform', in M. Geist (ed.), In the Public Interest: The Future of Canadian Copyright Law, Irwin Law, Toronto, pp. 437-461.

deBeer, J. and Geist, M. (2008) 'Developing Canada's IP Agenda', in J. Daudelin and Daniel Schwanen (eds), Canada Among Nations 2007: What Room for Manoeuvre? McGill-Queen's University Press, Montréal, pp. 157-180.

deBeer, J. (2009) Copyright and Innovation in the Networked Information Economy, Working Paper [online]. Available at $<$ http://ssrn.com/abstract=1410158 $>$ [Accessed on October 2009].

Drassinower, A. (2005) 'Taking User Rights Seriously', in M. Geist (ed.), In the Public Interest: The Future of Canadian Copyright Law, Irwin Law, Toronto, pp. 462-479.

Dusollier, S. (2003) 'Fair Use by Design in the European Copyright Directive of 2001', Communications of the ACM, 46(4), 51-55.

Ganley, P. (2004) 'Digital Copyright and the New Creative Dynamics', International Journal of Literature of Law \& Information Technology, 12(3), 282-332 .

Gasser, U. and Girsberger, M. (2004) Transposing the Copyright Directive: Legal Protection of Technological Measures in EU-Member States, A Genie Stuck in a Bottle?, Berkman Publication Series, No. 2004-10 (November) [online]. Available at $<$ http://papers.ssrn.com/sol3/papers.cfm?abstract_id=628007 > [Accessed on October 2009].

Gasser, U. (2006) 'Legal Frameworks and Technological Protection of Digital Content: Moving Forward towards a Best Practice Model', Fordham Intellectual Property, Media \& Entertainment Law Journal, 17(Fall), 39-113.

Geist, M. (2002) 'Key Case Restores Copyright Balance', The Globe and Mail, 18 April 2002, page B16.

Geist, M. (2005) 'Anti-circumvention Legislation and Competition Policy: Defining a Canadian Way?', in M. Geist (ed.), In the Public Interest: The Future of Canadian Copyright Law. Irwin Law, Toronto, pp.211-250. 
Geist, M. (2006) Our Own Creative Land: Cultural Monopoly \& The Trouble With Copyright. Hart House Lecture Committee, University of Toronto, 30 March.

Gervais, D. (2005) 'The Price of Social Norms: Towards a Liability Regime for File-Sharing', 12 Journal of Intellectual Property Law, 12(1), 39-74 [online]. Available at $<\underline{\text { http: } / / \text { ssrn.com/abstract }=525083}>$ [Accessed October 2009].

Gillepsie, T. (2007) Wired Shut: Copyright and the Shape of Digital Culture. The MIT Press, Cambridge, MA.

Ginsburg, J.C. (1999) 'Copyright Legislation for the 'Digital Millenium”, Columbia Journal of Law \& the Arts, 23(2), 137- .

Ginsburg, J.C. (2001) 'From Having Copies to Experiencing Works: the Development of an Access Right in U.S. Copyright Law', in H. Hansen (ed.), U.S. Intellectual Property Law and Policy. Edward Elgar, Northampton, MA, pp. [online]. Available at $<$ http://papers.ssrn.com/paper.taf?ABSTRACT_ID=222493 $>$ [Accessed on October 2009].

Government of Canada (2008a) Canada's Bill C-61: Questions and Answers [online]. Available at

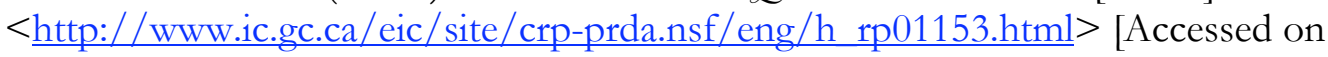
October 2009].

Government of Canada (2008b) Reforming the Copyright Act-Backgrounder [online]. Available at < http://www.ic.gc.ca/eic/site/crp-prda.nsf/eng/h rp01151.html> [Accessed on October 2009].

Government of Canada (2008c) Speech from the Throne 2008: Protecting Canada's Future [online].

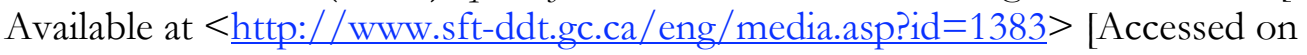
October 2009].

Heide, T. (2001) 'Copyright in the EU and U.S.: What Access Right?', Journal of the Copyright Society of the USA, 48(3), 363- [online]. Available at $<$ http://papers.ssrn.com/sol3/papers.cfm?abstract id=270861 > [Accessed on October 2009].

Herman, B.D. and Gandy, Jr., O.H. (2006) 'Catch 1201: A Legislative History and Content Analysis of the DMCA Exemption Proceedings', Cardozo Arts \& Entertainment Law Journal, 24, 121-190.

Herman, B.H. (2008) 'Breaking and Entering My Own Computer: The Contest of Copyright Metaphors', Communication Law \&o Policy, 13(2), 231-274 .

HM Treasury (2006) Gowers Review of Intellectual Property [online]. Available at $<\underline{\text { http://ec.europa.eu/internal market/copyright/docs/links/gowers report en.pdf }>}$ [Accessed on November 2009]

Hohfeld, W.N. (1946) Fundamental Legal Conceptions as Applied in Judicial Reasoning. Yale University Press, New Haven, CT.

Hugenholtz, P.B. (2000) 'Why the Copyright Directive is Unimportant, and Possibly Invalid, European Intellectual Property Review, 22(11), 501-502.

Institute for Information Law (2007) Study on the Implementation and Effect in Member States' Laws of Directive 2001/29/EC on the Harmonisation of Certain Aspects of Copyright and Related Rights in the Information Society, Final Report, [online]. Available at http://www.ivir.nl/publications/guibault/Infosoc report 2007.pdf [Accessed on October 2009].

Kerr, I.R., Maurushat, A. And Tacit, C.S. (2002-2003) 'Technical Protection Measures: 'Tilting at Copyright's Windmill', Ottawa Law Review, 34(1), 7-82. 
Kerr, I.R. (2005) 'If Left to Their Own Devices: How DRM and Anti-circumvention Laws Can Be Used to Hack Privacy', in M. Geist (ed.), In the Public Interest: The Future of Canadian Copyright Law, Irwin Law, Toronto, pp. 167-210.

Koelman, K.J. (2000a) 'A Hard Nut to Crack: The Protection of Technological Measures', European Intellectual Property Review, 22(6), 272-288.

Koelman, K. and Helberger, N. (2000b) 'Protection of Technological Measures', in P. Bernt Hugenholtz (ed.), Copyright and Electronic Commerce: Legal Aspects of Electronic Copyright

Management. Kluwer Law International, The Hague, pp. 165-227.

Litman, J. (1990) 'The Public Domain', Emory Law Journal, 39(Fall), 965-1023.

Litman, J. (2001) Digital Copyright. Prometheus Books, New York.

Michael Geist (2008) 61 Reforms to C-61, Day 40: TPMs - No Regular Review Process [online]. Available at < http://www.michaelgeist.ca/content/view/3297/99999/> [Accessed on October 2009].

Midgley, J. (2002) 'Critique of the Proposed UK Implementation of the EU Copyright Directive.' Available at <http://www.cfdr.eu.org/issues/eucd/ukimpl/critique uk impl.pdf $>$ [Accessed on November 2009].

Murray, L. (2005a) 'Bill C-60 and Copyright in Canada: opportunities Lost and Found', Canadian Journal of Communication, 30(4), 649-654.

Murray, L. (2005b) 'Copyright Talk: Patterns and Pitfalls in Canadian Policy Discourses', in M. Geist (ed.), In the Public Interest: The Future of Canadian Copyright Law, Irwin Law, Toronto, pp. 15-40.

Murray, L.J. and Trosow, S.E. (2007) Canadian Copyright: A Citizen's Guide. Between the Lines Press, Toronto.

Nimmer, D. (2000) 'A Riff on Fair Use in the Digital Millennium Copyright Act', University of Pennsylvania Law Review, 148(January), 673-742.

Olswang, S. (1995) 'Accessright: An Evolutionary Path for Copyright into the Digital Era?', European Intellectual Property Review, 17(5), 215-218.

Reichman, J.H., Dinwoodie, G.B. and Samuelson, P. (2007) 'A Reverse Notice and Takedown Regime to Enable Public Interest Uses of Technically Protected Copyrighted Works', Berkeley Technology Law Journal, 22, 981-1060.

Samuelson, P. (1996) 'Regulating Technologies to Protect Copyrighted Works', Communications of the ACM, 39(7), 17-22.

Samuelson, P. (1997) 'The U.S. Digital Agenda at WIPO', Virginia Journal of International Law, 37, 369-439.

Samuelson, P. (1999) 'Intellectual Property and the Digital Economy: Why the AntiCircumvention Regulations Need to be Revised', Berkeley Technology Law Journal, 14, 519566.

Samuelson, P. (2003) 'Mapping the Digital Public Domain: Threats and Opportunities', Law and Contemporary Problems, 66(Winter/Spring), 147-171.

Secor, G. (1997) 'Fair Use in a Pay-Per-Use World', Practice \& Theory, 21(1), 53-59.

Shah, A. (2004) 'UK's Implementation of the Anti-Circumvention Provisions of the EU Copyright Direction: An Analysis', Duke Law \& Technology Review, 3(January) [online]. Available at < http://www.law.duke.edu/journals/dltr/articles/2004dltr0003.html> [Accessed on November 2009]. 
Sookman, B.B. (2005) “TPMs": A Perfect Storm for Consumers: Replies to Professor Geist', Canadian Journal of Law \& Technology, 4(1), 23-43.

The State of Israel - Ministry of Justice (2009) 2009 Intellectual Property Law Submission of the Government of Israel to the United States Free Trade Representative with Respect to the 2009 "Special 301 Review" [online]. Available at <http://www.justice.gov.il/NR/rdonlyres/BD753811-E87A-4AB2-8ADDDC9423DFC794/13684/2009special301submission.pdf $>$ [Accessed on October 2009].

Wang, R.L. (2006) 'DMCA Anti-Circumvention Provisions in a Different Light: Perspectives from Transnational Observation of Five Jurisdictions' AIPLA Quarterly Journal, 34(Spring), 217-250.

Weatherall, K. (2004-05) 'Locked In: Australia Gets a Bad Intellectual Property Deal', Policy: a journal of public policy and ideas, 20(4), 18-24.

White Paper: Intellectual Property and the National Information Infrastructure (1995) The Report of the Working Group on Intellectual Property Rights [online]. Available at $<$ http://www.uspto.gov/web/offices/com/doc/ipnii/ipnii.pdf $>$ [Accessed on October 2009].

Wiese, H. (2002) 'Anti-circumvention Laws: A 'Circumvention' of the Copyright Balance in the Digital Age?’, Tolley's Communications Law, 7(5), 146-154 .

Winn, J.K. and Jondet, N.A. (2009) 'A 'New Deal' for End Users? Lessons from a French Innovation in the Regulation of Interoperability', William \& Mary Law Review, 51(2), forthcoming [online]. Available at $<\underline{\text { http://ssrn.com/abstract }=1419750}>$ [Accessed on October 2009]. 